\title{
The Emergence of Modern Physics Research in China: The Yenching Department of Physics and the Rockefeller Foundation ${ }^{1}$
}

\author{
Danian $\mathrm{Hu}$ 胡大年 2
}

(Department of History, The City College of The City University of New York, New York, NY 10031, US)

\begin{abstract}
Based on archival materials discovered in America, Britain, and China, this paper carefully examines the history of the short-lived and completely overlooked Department of Physics in the Premedical School of Peking Union Medical College (PUMC), and uncovers this department's extensive interconnections with its counterpart at Yenching University. This project also looks into the Master of Science (MS) program in the Department of Physics at Yenching University, which, founded in 1927, was the first graduate program in physics in China. It was this MS program that transformed the Yenching Department from a largely premedical training center serving the PUMC into a prominent cradle of Chinese physics research. This Yenching Department, despite its small faculty and brief existence, nurtured many eminent Chinese physicists, such as Chao-Ying Meng 孟昭英, Wen-Yu Chang 张文裕, Ming-Chen Wang 王明贞, Chia-Liu Luke Yuan 袁家骝, Cheng-Shu Wang (Chang) 王承书, Ho-Fu Lu 卢鹤线, Ting-Sui Ke 葛庭燧, Kun Huang 黄昆, and Chia-Lin Hsieh 谢家麟. It would have been impossible to achieve these outstanding accomplishments without the effective leadership and pioneering work of C. H. Corbett, P. A. Anderson, Y. M. Hsieh, and W. Band -the first four Department Chairs -in combination with relatively abundant private funding, mostly from America, and extensive educational connections with Western institutions. This paper not only introduces in detail these four department heads and their contributions, but also discloses the unique role played by the Rockefeller Foundation via the China Medical Board and the PUMC in the development of the Yenching Department of Physics.

Keywords: The Premedical School of the Peking Union Medical College, the Department of Physics at Yenching University, the China Medical Board, the Rockefeller Foundation, William Warren Stifler (1883-1954), Charles Hodge Corbett (1881-1963), Paul Alexander Anderson (1898-1990), Yu-Ming Hsieh (1895-1986),
\end{abstract}

1 This article has been copy-edited by John Moffett.

2 Research interests: The history of modern physics and twentieth-century history of Chinese science and technology. Email: danian.hu@aya.yale.edu 
William Band (1906-1993)

摘 要: 根据在美、英、中三国发现的原始档案材料, 本文仔细考察了此前完全被忽视 的协和医学院预科学校物理系的短暂历史, 并揭示了该系与燕京大学 (简称燕大) 物理 系之间的密切联系。本研究还深入调查了创立于 1927 年的燕大物理系硕士研究生项目, 这是中国第一个物理学研究生项目。正是这一研究生项目, 将燕大物理系由一个主要帮 助协和医学院准备合格医科学生的培训中心, 转变成为中国物理学研究工作的一处重要 发源地。燕大物理系的教授很少而且历史短暂, 然而从那里却走出了许多杰出的中国物 理学家, 如孟昭英、张文裕、王明贞、袁家骝、王承书、卢鹤绂、葛庭燧、黄昆和谢家 麟。这些突出成就的取得与该系头四位系主任郭查理、安德森、谢玉铭和班威廉的富有 成效的领导和开拓性工作密不可分, 同时也得益于相对充裕的、主要来自美国的私募经 费以及与西方教育机构的深厚联系。本文不仅详细介绍了这四位物理系的领军人物及其 贡献, 而且展示了洛克菲勒基金会通过中华医学基金会与协和医学院在燕大物理系发展 过程中所发挥的独特作用。

关键词: 协和医学院预科学校, 燕京大学物理系, 中华医学基金会, 洛克菲勒基金会, W. W. Stifler (1883-1954), 郭查理 (C. H. Corbett, 1881-1963), 安德森 (P. A. Anderson, 1898-1990), 谢玉铭（1895-1986), 班威廉 (William Band, 1906-1993)

\section{Introduction}

$\mathrm{T}$ wo weeks before the cornerstone for the first building of the Peking Union Medical College (PUMC) in Beijing 3 was laid, the College's Premedical School opened on September 11, 1917 with a mere eight students (Haas 1996, 10). The PUMC, established in 1915 and funded by the Rockefeller Foundation (RF) as part of the Protestant missionary effort in China, was designed to promote modern medical education in China. It went on to become "the most famous medical education and research center," not only in China but "all of Asia" (Ma 2002, 179; Haas 1996, 6). The influence of the PUMC, however, was not limited to medical education. It actually "had a far wider impact on higher education throughout China" because of its Premedical School, which laid stress on student participation in laboratories. In order to prepare qualified medical students, the China Medical Board (CMB), a subsidiary of the Rockefeller Foundation, chose to set up a Premedical School associated with the PUMC, a three-year school that offered college-grade courses in departments of physics, chemistry, biology, Chinese, and modern [Western] languages. In the following eight years, the school demonstrated "the teaching of the fundamental sciences at a high academic level, with emphasis on student participation in the laboratories." This kind of science instruction became a role model that soon inspired and encouraged colleges and universities all over China to

3 During the first half of the twentieth century, the city of Beijing was also referred to in the West as Peking and Peiping. Except for direct quotes from primary sources and the proper names of institutions, I refer to the city as Beijing throughout. 
raise their own standards of science teaching (Ferguson 1970, 37-39; Edwards 1959, 160; The Rockefeller Foundation China Medical Board 1918, 14-16). ${ }^{4}$

All science departments in the Premedical School (hereafter the School for short) soon shared courses with their counterparts of nearby Yenching University, another Protestant "union" institution organized one year after the School, making direct and substantial contributions to science teaching at the university. Because the annual enrollment of the School was very low, the PUMC decided to invite students of Yenching University (hereafter Yenching) to share physics, chemistry, and biology lectures and relevant laboratories in Lockhart Hall (Figure 1), a two-story Victorian-style building and the home of the School (Edwards 1959, 103, 161). ${ }^{5}$ Struggling with a shortage of laboratory equipment as well as high-quality science instructors, Yenching eagerly welcomed such a generous offer: "This was a great boon to Yenching and lifted the science work to a high level," Dwight W. Edwards, a former acting president of Yenching, later remarked (ibid., 103, 161). According to Chao-Ying Meng 孟昭英 (1906-1995), a well-known Chinese physicist and an early graduate of Yenching who took courses in Lockhart Hall, "the teaching quality of general physics

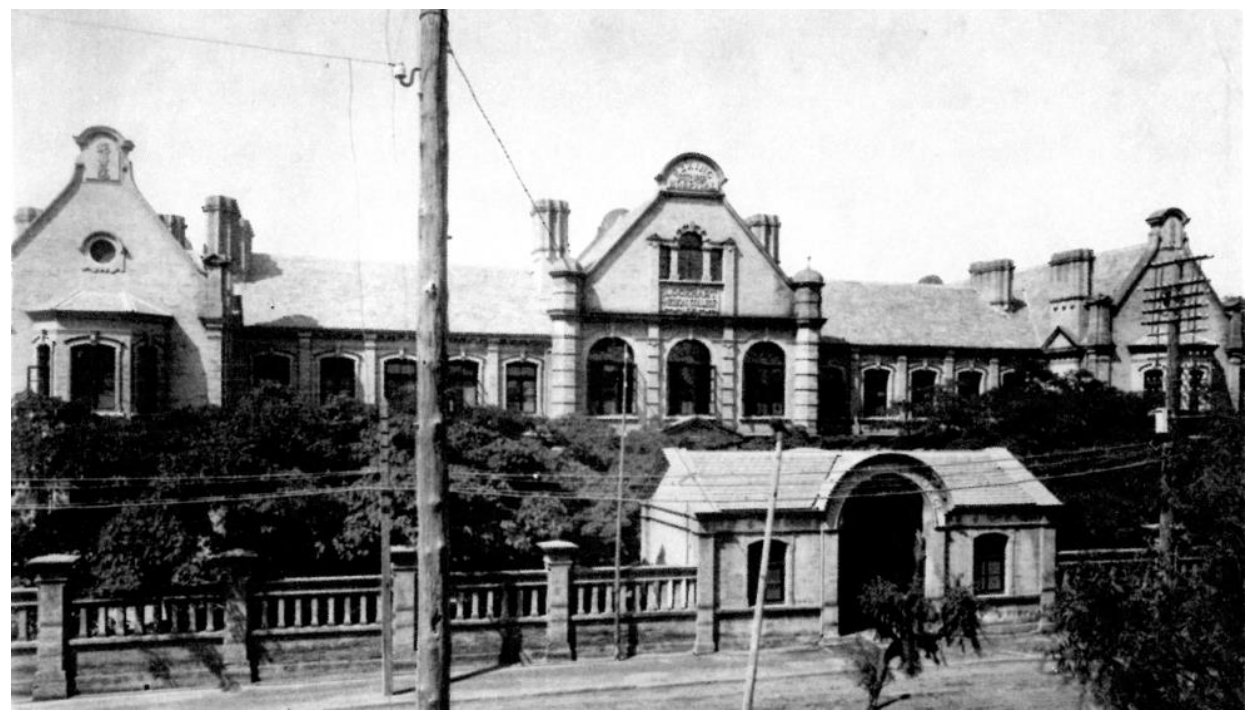

Figure 1: Lockhart Hall, the home of the PUMC's Premedical School. Credit: Ferguson 1970, following page 64 .

4 The departments of physics, chemistry, and biology were respectively headed by William W. Stifler, Stanley D. Wilson, and Charles Packard. For more information about the Premedical School in its early years, see The Rockefeller Foundation China Medical Board 1918, 14-16.

5 Enrollment numbers for the School in 1917, 1919, and 1923 were 8, 26, and 28 respectively, with a total of only 205 students admitted from 1917 to 1925. See Ferguson 1970, 38-39; Haas 1996, 4. Before 1926, Yenching had two separated campuses, Dengshikou 灯市口 (or Teng Shih Kou) and Kuijiachang 盔甲厂 (or Kuei Chia Chang), which were about six minutes and half an hour walking distance respectively from Lockhart Hall. 
was quite high" and the lectures in the Premedical School were lively and assisted with many in-class demonstrations and the use of lantern-slide shows (Meng 1982, 653). ${ }^{6}$

In fact, the PUMC and Yenching University collaborated with each other from early on. When the PUMC formally opened in late September 1921, it was John Leighton Stuart, Yenching's president, who delivered the prayer at the College's dedication. At its meetings in Beijing during this opening ceremony, the CMB decided to get rid of the School while also attempting to maintain the quality of future admissions to the PUMC. The scheme was to advance high-quality premedical education elsewhere in China, especially at Yenching (Haas 1996, 7, 11). ${ }^{7}$ By 1926, the CMB had turned over the entire School, including its library collections and laboratory apparatus, to Yenching. Stanley D. Wilson, the last dean of the School, later headed the College of Natural Sciences at Yenching. ${ }^{8}$ The transfer of the School to Yenching greatly boosted teaching and research in the latter's science departments, including that of physics. In subsequent years, Yenching supplied most of the PUMC medical and nursing students. The RF also continued its support for premedical education in biology, chemistry, and physics at Yenching, which, according to a 1929 report, had the strongest science departments among the contemporary mission schools in the country (Haas 1996, 204). The foundation's continued support reached a climax in 1930, when it provided a five-year grant of $\$ 250,000$ (US Gold) in total to cover the equipment costs and salaries of Yenching's science departments. ${ }^{9}$ Through the CMB, the RF gave grants to various mission schools, as well as to Chinese government and private universities around China, to develop science departments in existing colleges and universities so that they could eventually provide adequate preparation for medical study. The assistance was in various forms - buildings, equipment, salaries for increased personnel; financing of an educational conference in Shanghai of interested mission boards; graduate fellowships for teachers in the natural sciences, etc. (Ferguson 1970, 39). ${ }^{10}$ In terms of financial assistance for an institution's endowment security, however, this five-year grant to Yenching was probably the largest, single donation of aid the foundation ever

6 For the date of Meng's admission to Yenching, see Chao-ying Meng's 孟昭英 interview by Wang Delu 王德禄 and Kathleen Dugan 杜开昔, November 21, 1988, Beijing.

7 For the dates of the formal opening ceremony of the PUMC, see Ferguson 1970, 51.

8 A short biography by Wilson's daughter can be found in Yanjing Academic Research Institute 2001, 137.

9 For a detailed and fascinating story about this large RF grant offered to Yenching, see Haas 1996, 203-210.

10 The institutions receiving grants from the CMB included: Yenching University, the University of Nanking, Ginling College, Soochow University St. John's University, Yale-in-China, Fukien Christian University, and Canton Christian College (all mission-supported), as well as two Chinese government institutions, Southeastern University and Tsinghua College, and one private Chinese university, Nankai. 
handed out in China. ${ }^{11}$

In this paper, I carefully examine the evolution of a so far completely ignored institution, the Department of Physics in the PUMC Premedical School, and its extensive interconnections with its counterpart at Yenching University. On this basis, my study attempts to understand how the Yenching Department eventually emerged as a leading cradle of Chinese physics researchers, and to reveal the significant impact of the Rockefeller Foundation in these developments.

\section{The physicists in the PUMC Premedical School}

In June 1916, the PUMC Trustees appointed Franklin C. McLean, a twenty-eightyear-old physician at the Rockefeller Institute for Medical Research in New York City, as professor of Internal Medicine and PUMC's Academic Director, where he was responsible for selecting and recommending teaching staff to the board. It appears that McLean contacted Dr. William Warren Stifler (1883-1954) no later than early December, asking for the latter's curriculum vitae and references, as well as an estimated "first cost of a physics department" (Chandler and Novak 2010, 10; The Rockefeller Foundation China Medical Board 1918, 11). ${ }^{12}$ Having earned his PhD at the University of Illinois in Urbana, IL in 1911, Stifler joined the physics faculty at Columbia University in New York City, serving as assistant (1911-1912), lecturer (1912-1913), and instructor (1913-1917). He also taught at Columbia's College of Physicians and Surgeons (The Rockefeller Foundation China Medical Board 1918, 14-16; Ferguson 1970, 38; Chandler and Novak 2010, 10). ${ }^{13}$ In his letter to McLean, Professor G. V. Wendell, Stifler's supervisor at Columbia University, wrote, "I can without hesitation recommend him [Stifler] as a fine teacher, a man of promise in his profession, possessed of excellent administrative ability, and with initiative."14 Professor G. B. Pegram, the head of the

11 Thanks to Dr. William J. Haas for sharing with this author his expert opinions on this issue. In his email of October 8, 2019, he wrote: "Rockefeller money heavily supported other institutions' science education. There was money for labs and salaries and for buildings, but to my knowledge, there was never any consideration of grants to create permanent endowments whose earnings would take the place of yearly appropriations from the CMB or later the RF. That is, until the grant of $\$ 250 \mathrm{~K}$ was made to Yenching."

12 Also see Stifler to McLean, December 12, 1916, Folder 881 (Physics, 1921-1925), Box 121, RG IV2B9, CMB, Inc., Rockefeller Foundation records, Rockefeller Archive Center.

13 See also Stifler's CV, Folder 881 (Physics, 1921-1925), Box 121, RG IV2B9, CMB, Inc., Rockefeller Foundation records, Rockefeller Archive Center. Having received his AB (1902) at Shurtleff College, W. W. Stifler earned AM (1908) and PhD (1911) in physics at the University of Illinois. After returning to America from China, Stifler taught physics at Amherst College from 1925 to 1952. For the dates of Stifler's degrees and later academic career, see Stifler 1908; Stifler 1911; Del Regato 1978, 728.

14 Wendell to McLean, December 15, 1916, Folder 881 (Physics, 1921-1925), Box 121, RG IV2B9, CMB, Inc., Rockefeller Foundation records, Rockefeller Archive Center. 
Department of Physics at Columbia, also commended Stifler to McLean: "Dr. Stifler is a very good man. He has had a broad training in physics, is a fine teacher, and a man of promise in science" who had just helped Wendell set up "an entirely new laboratory of pyrometry and heat measurements." 15

Being "interested in any position that has a future," Stifler was clearly eager to discuss with McLean this prospective appointment in the PUMC Premedical School and was pleased to be considered as a candidate for the position. ${ }^{16}$ Nevertheless, he could not help questioning the CMB's wisdom to grant only the title of "Instructor" to the well trained men who were put in charge of the science departments. In his letter to McLean, Stifler pointed out that the science teaching in the School "[was] intended to be on par with that offered in the freshman or sophomore years of our first class universities and colleges. The man in charge of such a course [in America was] almost invariably of professorial rank." Moreover, he argued that letting men with lower rank teach these subjects would "cheapen the work in the fundamental sciences in the eyes of the Oriental students" as well as "in the minds of educators in China." Last but not least, Stifler attempted to draw McLean's attention to the "distinct advantage" for the School faculty when they returned to the United States if they could have a professorial title. In his reply, McLean told Stifler that the CMB had given "considerable thought" to these issues, and decided "not to give the formal rank of professor to those not teaching in the Medical School proper." According to McLean, "The title of Instructor [was] meant to be descriptive rather than formal." Although McLean promised to take the subject before the CMB again, he discouraged Stifler from expecting any change soon. ${ }^{17}$

These exchanges between Stifler and McLean not only demonstrate different attitudes of the CMB toward the faculty in the Premedical and the Medical Schools, but also hint that the board did not have a long-term plan for the Premedical School. ${ }^{18}$ In fact, while setting it up, "the CMB simultaneously began to provide financial support for premedical education in selected Chinese colleges with an eye toward discontinuing PUMC's premedical curriculum" (Chandler and Novak 2010, 10). It appears that Stifler

15 Pegram to McLean, December 15, 1916, Folder 881 (Physics, 1921-1925), Box 121, RG IV2B9, CMB, Inc., Rockefeller Foundation records, Rockefeller Archive Center.

16 Stifler to McLean, February 10, 1917, Folder 881 (Physics, 1921-1925), Box 121, RG IV2B9, $\mathrm{CMB}$, Inc., Rockefeller Foundation records, Rockefeller Archive Center. Stifler's enthusiasm is obvious in his correspondence with McLean.

17 Stifler to McLean, February 23, 1917, Folder 881 (Physics, 1921-1925), Box 121, RG IV2B9, CMB, Inc., Rockefeller Foundation records, Rockefeller Archive Center; McLean to Stifler, March 12, 1917, Folder 881 (Physics, 1921-1925), Box 121, RG IV2B9, CMB, Inc., Rockefeller Foundation records, Rockefeller Archive Center.

18 In his book, William Haas points out that "the premedical faculty had a lower salary scale than the medical school faculty." But Stifler wrote in February 1917 that the "Instructor" chairing the science departments in the Premedical School had salaries "substantially the same as those paid to the Professors in the Medical College proper" (Haas 1996, 9; Stifler to McLean, February 23, 1917). 
was not aware of the CMB's decision concerning the School's future until the end of 1922 (Haas 1996, 9-10). As a result, when the Board of Trustees of the PUMC officially appointed him as "Instructor in Physics" in the School in mid-April 1917, Stifler quickly accepted. After all, Stifler had declared to McLean that he "never [had] been much of a stickler for titles." Stifler's appointment took effect on July $1 .{ }^{19}$

Sailing on the Empress of Russia from Vancouver on August 2, 1917, Stifler arrived in Beijing in time to attend the opening ceremony of the School on September 11.20 Soon after Stifler's arrival at PUMC, he appointed the School's first "Assistant in Physics," Yung-Tso Tong (1889-?), who had earned two BS degrees, one in civil engineering at the University of Illinois and another in sanitary engineering at Pittsburgh University (Ferguson 1970, 38). ${ }^{21}$ Apart from teaching, Stifler was also busy planning and ordering "apparatus for Physics laboratory and shop" with his annual budget of $\$ 6000$ in $1917 .{ }^{22}$

Apparently satisfied with Stifler's performance as the department head in Beijing, the Executive Committee of the Trustees of the PUMC passed a resolution on February 25, 1918 to appoint him the newly created Dean of the Premedical School beginning on January 1, 1918. Responding to this new appointment, Stifler wrote: "To say that I was greatly surprised and pleased expresses the matter very mildly. I am very glad to accept the additional duties and assure you that I shall do everything in my power to make the work a success." 23 By June, Henry S. Houghton, the acting General Director of the CMB who was also in charge of the PUMC at that time, had reported "that the Pre-Medical School is practically past being a source of anxiety to me and that the men that are there and that are yet to come will make the Pre-Medical School an unusually efficient and satisfying institution." 24

With additional administrative work in the School, and an increase in enrollment in

19 McLean to Stifler, April 12, 1917, Folder 881 (Physics, 1921-1925), Box 121, RG IV2B9, CMB, Inc., Rockefeller Foundation records, Rockefeller Archive Center; McLean to Greene, April 30, 1917, Folder 881 (Physics, 1921-1925), Box 121, RG IV2B9, CMB, Inc., Rockefeller Foundation records, Rockefeller Archive Center; Stifler to McLean, February 23, 1917.

20 Buttrick to Stifler, June 25, 1917, Folder 881 (Physics, 1921-1925), Box 121, RG IV2B9, CMB, Inc., Rockefeller Foundation records, Rockefeller Archive Center.

21 Mary E. Ferguson, 38; Tong, Yung-tso, Physics-Staff, Folder 881 (Physics, 1921-1925), Box 121, RG IV2B9, CMB, Inc., Rockefeller Foundation records, Rockefeller Archive Center.

22 Stifler to McLean, January 8, 1918, Folder 881 (Physics, 1921-1925), Box 121, RG IV2B9, CMB, Inc., Rockefeller Foundation records, Rockefeller Archive Center.

23 McLean to Stifler, March 4, 1918, Folder 881 (Physics, 1921-1925), Box 121, RG IV2B9, CMB, Inc., Rockefeller Foundation records, Rockefeller Archive Center; Stifler to McLean, April 8, 1918, Folder 881 (Physics, 1921-1925), Box 121, RG IV2B9, CMB, Inc., Rockefeller Foundation records, Rockefeller Archive Center.

24 McLean to Stifler, July 2, 1918, Folder 881 (Physics, 1921-1925), Box 121, RG IV2B9, CMB, Inc., Rockefeller Foundation records, Rockefeller Archive Center. Houghton acted as General Director and Resident Director of the CMB from at least mid-1917: The Rockefeller Foundation China Medical Board 1918, 11, 28. 
physics lectures and laboratories since 1918 (Yenching students might well have come to Lockhart Hall as early as fall 1918), Stifler wanted someone to share the teaching load with him in the department. The departure of Y. T. Tong, the Assistant in Physics, only made new appointments in the department more urgent. ${ }^{25}$ Finding a qualified Instructor or Assistant in Physics who was willing to come to PUMC, however, was not easy. ${ }^{26}$ It was not until April 1919 that McLean received a candidate's name, Bird R. Stephenson, from the University of Illinois, Stifler's alma mater. Stephenson had earned his MS in 1917 at the university and taught there in 1917-1918 (The Rockefeller Foundation 1919, 291). McLean first wrote to Stephenson on April 30; within a mere four weeks, he wired Stephenson an official appointment: "Instructor in Physics in the Peking Union Medical College for a term of three years at an annual salary of \$1800." 27 Meanwhile, the School also appointed Ma Ming-hsi, likely as a new Assistant in Physics, for 1919-1920 (Ferguson 1970, 243). ${ }^{28}$ When Ma's one-year appointment expired, Stifler had to look for another assistant in America in 1920. Despite Stifler's reluctance, the $\mathrm{CMB}$ once again recruited a young Chinese physicist educated in America.

Having learned of the opening at the PUMC, Paul Chi-Ting Kwei 桂质廷 (1895-1961) applied for it in June 1920 from Washington, DC, where he was working on a special project at the Bureau of Standards. ${ }^{29}$ Born to a Chinese Christian pastor's family, Kwei was an Episcopalian who began his school education in the American Church Anglo-Chinese Graded School in Shashi, Hubei. In 1909, Kwei went to Shanghai and enrolled in St. John's College, where he studied for three years before

25 It must be quite challenging for Tong to work under Stifler because of the latter's demanding requirements for his assistant. In May 1921, Stifler submitted a memo to the Director of the PUMC, in which he specified his requirements and concerns about appointing an Assistant in Physics: "This man should be an American. A Chinese returned student will not meet the needs, since much of the time of this man must be spent in correcting laboratory reports which are criticized for the English as well as for the physics involved." William W. Stifler, "Memorandum Concerning Assistant in Physics," Folder 881 (Physics, 1921-1925), Box 121, RG IV2B9, CMB, Inc., Rockefeller Foundation records, Rockefeller Archive Center (May 1921).

26 Houghton to Vincent, September 21, 1920, Folder 881 (Physics, 1921-1925, Physics-Staff, Kwei, Chi-ting), Box 121, RG IV2B9, CMB, Inc., Rockefeller Foundation records, Rockefeller Archive Center.

27 McLean to Stephenson, April 29, 1919, Folder 881 (Physics, 1921-1925), Box 121, RG IV2B9, CMB, Inc., Rockefeller Foundation records, Rockefeller Archive Center; McLean to Stephenson, May 27, 1919, Folder 881 (Physics, 1921-1925), Box 121, RG IV2B9, CMB, Inc., Rockefeller Foundation records, Rockefeller Archive Center.

28 No additional information about Ma is available at present.

29 Eggleston to Kwei, July 16, 1920, Folder 881 (Physics, 1921-1925, Physics-Staff, Kwei, Chi-ting), Box 121, RG IV2B9, CMB, Inc., Rockefeller Foundation records, Rockefeller Archive Center; Vincent to Houghton, July 19, 1920, Folder 881 (Physics, 1921-1925; Physics-Staff, Kwei, Chi-ting), Box 121, RG IV2B9, CMB, Inc., Rockefeller Foundation records, Rockefeller Archive Center. Since the letter of support for Kwei's application was dated June 19, 1920, Kwei must have filed his application around the same time. 
transferring to Tsinghua (or Tsing Hua) College in Beijing. Upon graduation, he taught English in Tsinghua Middle School for a year before going to America in 1914 to study at Yale University. Kwei changed his major at Yale from economics to physics, earning his BA in 1917, and subsequently beginning his graduate studies at the University of Chicago. In response to a call from Young Men's Christian Association (YMCA), however, he left Chicago and joined with dozens of Chinese students in America, including his friend at Yale Y. C. James Yen 晏阳初 (1893-1990), to travel to France in April 1918 to help tens of thousands of Chinese laborers working for the Allies in WWI. When he returned to America in June 1919, Kwei enrolled in Cornell University, where he was a Susan[na] Phelps Gage Fellow, receiving his MS one year later. As soon as he graduated from Cornell, he filed his application for the PUMC position (Qian and Chen 2014, 104-106). ${ }^{30}$

To support Kwei's application, Professor Ernest G. Merritt, the first dean of Cornell Graduate School and the head of the Department of Physics of Cornell University, wrote in his recommendation letter, "Mr. Kwei is a very attractive man personally and has unusually good command of English and French. In physics certainly and probably in other lines his natural ability is distinctly above the average." Soon after interviewing Kwei in New York, George E. Vincent, president of the RF and the CMB Chairman, wrote to Houghton, Resident Director of the CMB in China and the would-be PUMC Director, on July 19, "Mr. Kwei has made a very favorable impression on us here and seems to be very earnest and enthusiastic. His English is perfect and without accent." In his postscript, Vincent added, "The recent cablegram from Peking about Mr. Kwei has been received. We feel that he meets the requirements for an assistant in physics extremely well and might develop into a candidate for an instructorship." 31

Two weeks later, on August 5, 1920, the Executive Committee of the Trustees of the PUMC informed Kwei by mail his official appointment as Assistant in Physics at the PUMC "for three years beginning September 1, 1920, at an annual salary of \$1,200 gold, or Mex. 2,400." 32 Kwei was very happy with the appointment and replied immediately, "deem[ing] it a real honor and privilege." 33 According to the CMB's arrangement,

30 Also see Vincent to Houghton, July 19, 1920. The Susanna Phelps Gage Fellowship was established in 1918 by Professor Simon Henry Gage for research in physics (https:// ecommons.cornell.edu/bitstream/handle/1813/18361/Gage_Simon_Henry_1944.pdf?sequence= 2\&isAllowed=y, accessed July 2, 2019).

31 Vincent to Houghton, July 19, 1920. The information on Prof. Merritt: http://rmc.library. cornell.edu/EAD/htmldocs/RMA00046.html, accessed July 3, 2019.

32 Eggleston to Kwei, August 5, 1920, Folder 881 (Physics, 1921-1925, Physics-Staff, Kwei, Chi-ting), Box 121, RG IV2B9, CMB, Inc., Rockefeller Foundation records, Rockefeller Archive Center.

33 Kwei to Eggleston, August 8, 1920, Folder 881 (Physics, 1921-1925, Physics-Staff, Kwei, Chi-ting), Box 121, RG IV2B9, CMB, Inc., Rockefeller Foundation records, Rockefeller Archive Center. 
Kwei should leave DC on September 15 and sail from San Francisco on the "Nanking" ten days later on the 25 th. ${ }^{34}$

Upon receiving news of the official appointment of Kwei, Houghton wrote enthusiastically on September 21 to Vincent,

We are very fortunate[,] I am sure[,] to have a young man of so much promise, and I am glad to say that Mr. Stifler seems especially pleased with the record and recommendations which he has for this post. Our minds are greatly relieved with this appointment, since the junior positions in the Premedical School are apparently difficult ones satisfactorily to fill. ${ }^{35}$

It turned out, however, that Stifler was initially not enthusiastic about Kwei's appointment, as Houghton thought. Stifler held a deep prejudice against appointing returned Chinese students, distrusting especially their English proficiency, until, that is, he witnessed Kwei's performance at PUMC. In a memorandum sent four months later to Richard M. Pearce, the interim PUMC Director (1920-1921) and the General Director of the RF's Division of Medical Education, Stifler confessed,

\begin{abstract}
At the time that Mr. Kwei's appointment was suggested, I was rather loth to agree to it, as I feared that a Chinese would not meet the needs in the Physics Department. In some degree my judgment in this matter has been justified, as Mr. Kwei has several of the failings and defects which I foresaw in any Chinese. At the same time[,] he has excellent general training and native ability. A few of his difficulties come from lack of teaching experience, and this he is overcoming rapidly. His acquaintance with Peking is extremely valuable to us, and in many cases his pleasing personality and general force of character make him as a Chinese more valuable than a foreigner of similar training would be. All things considered, I think he will develop into a valuable asset to the department, if he can be made a reasonably permanent member of it.
\end{abstract}

Facing the competition from the authorities of Yale-in-China, who were working hard to secure Kwei's services by June 1922, Stifler prepared this memorandum to convince the RF and the CMB that it was important and advantageous for the School to retain Kwei, even at a price that met Kwei's personal requests. To accomplish this goal, Stifler proposed that the CMB consider granting Kwei an RF Fellowship, and Helen Huie, Kwei's fiancée, a scholarship and a travel allowance. While the fellowship would help Kwei to complete his work for PhD in America and secure his further service in the School after his return, the scholarship and the travel allowance were to enable Miss

34 Vincent to Houghton, July 19, 1920. The coastal liner "Nanking" ran the San Francisco-Hong Kong route (http:/ / www.yorkship.org/HTML/liners.htm, accessed July 3, 2019).

35 Vincent to Houghton, September 21, 1920, Folder 881 (Physics, 1921-1925; Physics-Staff, Kwei, Chi-ting), Box 121, RG IV2B9, CMB, Inc., Rockefeller Foundation records, Rockefeller Archive Center. 
Huie to finish her study at Cornell Medical School and to come to China, joining Kwei in the PUMC. ${ }^{36}$ Over the next several months, Stifler repeatedly petitioned on Kwei's behalf for the CMB's support. Although both Pearce and Roger S. Greene, Resident Director of the CMB in China, supported Stifler's proposal, the CMB seemed to be only "[r]eady to approve fellowship for Kwei," arguing that the rest of the requests from Kwei, Stifler, and the PUMC were "contrary" to the board's policy. ${ }^{37}$

To date, no document concerning the CMB's resolution on Kwei has been found. We know, however, that Yale-in-China contacted the CMB directly in June 1921, inviting Kwei to serve as head of the Department of Physics at the College of Yale-in-China in Changsha 长沙雅礼大学, and hoping that the PUMC would release him in Spring 1922. Yale-in-China also promised to cover the expenses for Miss Huie's trip to China. ${ }^{38}$ Eventually, Kwei accepted the offer from Changsha and resigned from the PUMC in June 1922, one year before the expiration of his appointment in the School. ${ }^{39}$

After teaching in Changsha for a year, Kwei did receive an RF Fellowship of \$1000 in May 1923, which was later renewed for a second year. The fellowship allowed him to return to America in 1923 to study with K. T. Compton at Princeton University, where he earned his PhD in 1925. Kwei would go on to become a distinguished educator and research physicist in China, and is considered as a pioneer in the Chinese study of geomagnetism, and aeronomy and ionosphere physics (Qian and Chen 2014, 1, 104).40

Six months before Kwei's departure from the PUMC, Houghton had reported the young Chinese assistant's intended resignation on January 5, 1922. It is remarkable, and likely not coincidental, that on the same day Houghton also informed Greene of Stifler's decision of "definitely leaving [the Premedical School] permanently at the end of this [academic] year." 41 As early as Spring 1921 Stifler might well have realized that the PUMC Premedical School would not survive beyond 1925, and thus began to

36 William W. Stifler, "Memorandum Concerning the Case of Mr. C. T. Kwei," Folder 881 (Physics, 1921-1925; Physics-Staff, Kwei, Chi-ting), Box 121, RG IV2B9, CMB, Inc., Rockefeller Foundation records, Rockefeller Archive Center (January 20, 1921).

37 This is a summary of the correspondence among Stifler, Pearce, Greene, and Kwei, which are deposited in the folder as shown in the following citation. The quotes appear in Embree to Houghton, February 24, 1921, Folder 881 (Physics, 1921-1925; Physics-Staff, Kwei, Chi-ting), Box 121, RG IV2B9, CMB, Inc., Rockefeller Foundation records, Rockefeller Archive Center.

38 Vreeland to Embree, June 15, 1921, Folder 881 (Physics, 1921-1925; Physics-Staff, Kwei, Chi-ting), Box 121, RG IV2B9, CMB, Inc., Rockefeller Foundation records, Rockefeller Archive Center.

39 C. T. Kwei, Resignation of C. T. Kwei, Folder 881 (Physics, 1921-1925, Physics-Staff, Kwei, Chi-ting), Box 121, RG IV2B9, CMB, Inc., Rockefeller Foundation records, Rockefeller Archive Center (June 19, 1922).

40 Also see "Kwei, Paul Chi-Ting," Box 16, Discipline 13: CMB Medical Fellowships; Premedical \& Miscellaneous Subjects, Chinese, Subgroup 2, RG 10.2, Fellowships, Fellowship Recorder Cards, FA426, Rockefeller Foundation records, Rockefeller Archive Center.

41 Houghton to Greene, January 5, 1922, Folder 881 (Physics, 1921-1925), Box 121, RG IV2B9, CMB, Inc., Rockefeller Foundation records, Rockefeller Archive Center. 
consider leaving the PUMC. Stifler was scheduled to be on furlough in 1922-1923, the last year of his term of service. Instead of returning to America, however, he spent the year at Canton Christian College (Lingnan University 岭南大学) in Guangzhou, China. ${ }^{42}$ Before his departure from Beijing, Stifler completed and submitted his manuscript of a practical and enlightening textbook that went on to influence many Chinese students of physics in the 1920s and 1930s.

Based on his teaching experience at PUMC, Stifler developed a new laboratory manual to meet the needs of Chinese students in an introductory course in physics offered in the first year of the School. In this course, he used popular American physics textbooks, but found that the accompanying laboratory manuals were not suitable for his class because "many questions and problems, especially in mechanics, refer[ed] to matters utterly foreign to the experience of the average youth in China." In his new manual, Stifler adapted ideas and methods from American textbooks "to the conditions and environment of the Chinese students." His "idea and ideal" in designing thirty-three exercises was to demonstrate to students "the fact that a physics laboratory is not a place in which he goes through more or less meaningless performances to please the instructor, but rather one where he is taught to investigate, to tabulate data and results logically, and above all, to think." Only after his exercises "had stood the test of actual use with three successive classes and had passed through as many mimeographed 'editions'," did Stifler submit in the summer of 1922 his revised manuscript to the Commercial Press for publication under the title Exercises in Elementary Physics. The Commercial Press was the first modern publishing house in China, widely known for its publication of high-quality and popular science textbooks. Stifler's Exercises first appeared in June 1923, and was in so much demand that the publisher issued a second edition in the following year. It was also repeatedly reprinted in the decade that followed. It was particularly influential among physics students at Yenching, because it was among the list of essential readings for applicants for the Department of Physics. The book may well have inspired two faculty members at Yenching University to design and publish a new textbook in general physics based on Chinese situations, which will be discussed in the following section. As Stifler acknowledged, both Stephenson and Kwei contributed to the improvement of Exercises with their "valuable suggestions and criticisms," which likely emerged from

42 In late March 1921, when Stifler planned the School's budget for the next five years, he remarked on the year 1923-1924, "It will be necessary to appoint an Assistant Professor or Professor to take charge of the department for this year, in case Mr. Stifler is not reappointed, or declines reappointment." See William W. Stifler, "Excerpt from Dr. Stifler's Memorandum concerning Salaries, Personnel, and New Equipment," Folder 881 (Physics, 1921-1925; Physics-Staff, Stifler, William W.), Box 121, RG IV2B9, CMB, Inc., Rockefeller Foundation records, Rockefeller Archive Center (March 25, 1921); Greene to Jaqua, April 17, 1925, Folder 881 (Physics, 1921-1925), Box 121, RG IV2B9, CMB, Inc., Rockefeller Foundation records, Rockefeller Archive Center. 
their use of it when teaching (Stifler 1923, "Preface").43

With the planned departure of both Stifler and Kwei from the School in summer 1922, the Department of Physics clearly faced a serious shortage of teaching staff for the next three years before the School was scheduled to close in 1925. Houghton, now the PUMC Director, acted quickly to deal with the situation by: (1) asking Charles Hodge Corbett 郭查理 (1881-1963), chairman of the Yenching Department of Physics, to take Stifler's place; (2) amalgamating collegiate courses in physics at Yenching with those in the Premedical School and carrying out the teaching at Lockhart Hall; (3) extending Stephenson's appointment for another three years. ${ }^{44}$

When Houghton reported to the CMB on January 5, 1922 recommending that Corbett take charge of the School's Department of Physics after Stifler's departure, Corbett had just arrived in Chicago to begin his advanced study for premedical education. As part of the CMB's plan on cooperation in premedical teaching between the PUMC and Yenching University, Charles Corbett was given a one-year fellowship to further his "training in the higher branches of physical science" in late October 1921. In retrospect, this move clearly indicated the board's intention to transfer the Premedical School to Yenching, but the plan must have remained undisclosed then, as Corbett was completely surprised when he received the offer. The board selected Corbett because he was considered "one of the best teachers of physics in the Orient." 45

Corbett left Beijing on December 7, arrived in Chicago on December 30, 1921, and registered at the University of Chicago on January 3, 1922. He chose to go to Chicago not only because of "its strong physics department" but also due to his preference for its quarter system, which would allow him to "complete three-quarters of study by [September 1]-equivalent to a full year's work elsewhere-and get bet back to Peking in time for the autumn's work." Having finished his study in America on schedule, Corbett sailed for China on September 7, 1922, where he was promoted to Associate Professor of Physics at Yenching University and Honorary Assistant Professor in PUMC Premedical School. ${ }^{46}$ The following picture (Figure 2) must have been taken after Corbett's return from America.

Early in 1921, Stifler had requested the CMB appoint another Assistant in Physics. With the announced departure of Kwei, this became urgent, and by late May 1922, the board had appointed Frank M. Exner. Having earned his BA from Carleton College in Minnesota in 1919, Exner went to Yale University in 1920, working for his doctorate in physics, where,

43 The latest reprint I have found was published in January 1933. On the essential reading list for the Yenching Department of Physics, see ibid.

44 Houghton to Greene, January 5, 1922.

45 "Corbett, Charles Hodge," Box 16, Discipline 13: China Medical Board (CMB) Medical Fellowships; Premedical \& Miscellaneous Subjects, Chinese, Subgroup 2, RG 10.2, Fellowships, Fellowship Recorder Cards, FA426, Rockefeller Foundation Records, Rockefeller Archive Center. The CMB fellowship included a stipend of $\$ 1,000$ and traveling allowance of $\$ 1,200$.

46 Ibid. 
according to his professor, he served as a laboratory assistant and hence was "thoroughly conversant with our methods of teaching physics in the laboratory." 4748 In September 1922, the CMB also appointed a native Chinese, David King Yang 杨荩卿, who had graduated from Shantung Christian University (Cheeloo University, 齐鲁大学) in 1912, as Assistant in Physics. Yang's one-year appointment was annually renewed over the next two years until he eventually became a member of the physics faculty at Yenching when the entire School was transferred there and the two physics departments merged in 1925.49

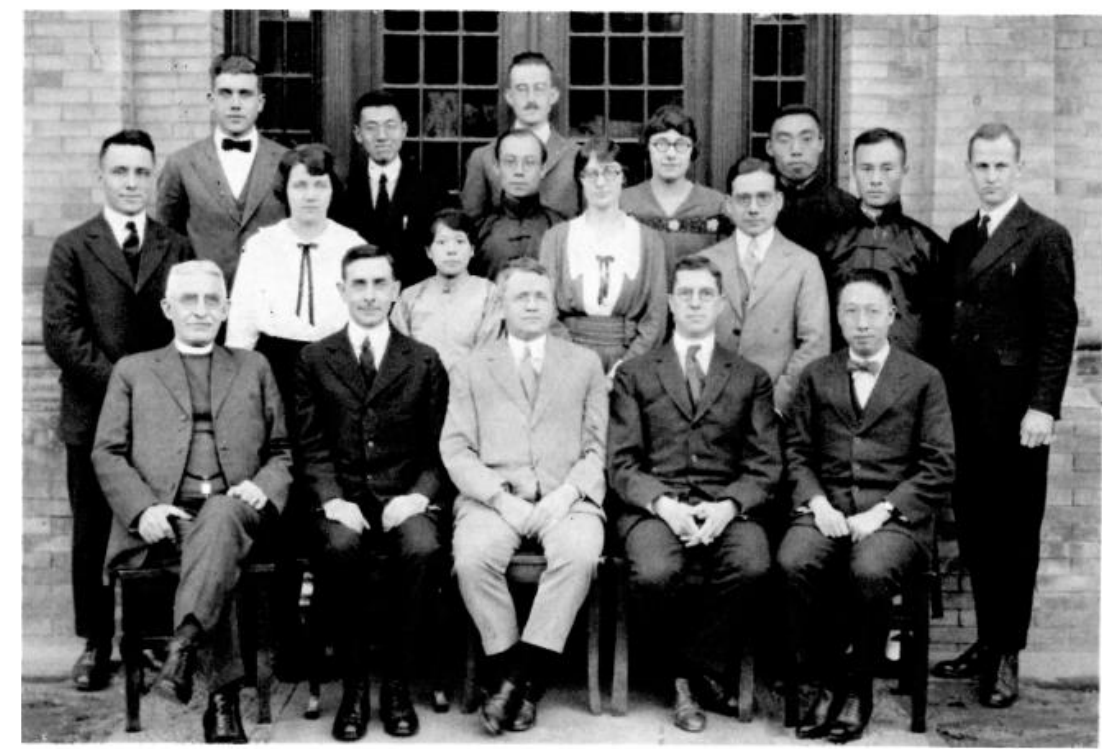

Figure 2: Faculty and Staff of the Premedical School, 1922-1923 - Left to right, front row: Rev. Lorin Webster, Rev. C. H. Corbett, Dr. S. D. Wilson, Dr. Charles Packard, Mr. Ma Kiam 马鑑; second row: Mr. B. R. Stephenson, Miss Emily Tilly, Miss Grace Huang, Miss Helen R. Downes, Mr. Aura E. Severinghaus, Mr. Yu I-fang, Mr. Frank M. Exner; third row: Mr. Leslie R. Severinghaus, Mr. N. K. Tang, Mr. E. C. Scott, Mr. C. M. Yu, Miss Edna Wolf, Mr. D. K. Yang 杨荩卿.

47 Zeleny to Well, December 12, 1921, Folder 881 (Physics, 1921-1925, Physics-Staff, Exner, Frank M.), Box 121, RG IV2B9, CMB, Inc., Rockefeller Foundation records, Rockefeller Archive Center. 48 F. M. Exner, BA, was an assistant in the Physics Department and acted as temporary assistant at the Observatory of Yale University during the summer of 1921 (Yale University President's Office 1922, 326); he worked for the Chemical Foundation in the early 1930s (Heilbron and Seidel 1989, 121). As a physicist of the Crocker Institute of Cancer Research at the Columbia-Presbyterian Medical Center in the late 1930s, Exner also constructed a million-volt X-Ray tube, an apparatus used as a powerful instrument in combating cancer ("Physicist Is Killed By Shock" 1937).

49 "Yang, David King," Box 16, Discipline 13: China Medical Board (CMB) Medical Fellowships; Premedical \& Miscellaneous Subjects, Chinese, Subgroup 2, RG 10.2, Fellowships, Fellowship Recorder Cards, FA426, Rockefeller Foundation records, Rockefeller Archive Center; Physics-Staff, Yang, David K., Folder 881 (Physics, 1921-1925), Box 121, RG IV2B9, CMB, Inc., Rockefeller Foundation records, Rockefeller Archive Center. 
Table 1 lists the eight faculty members who served in the Department of Physics of the Premedical School between 1917 and 1925. Most of these science teachers had already won their spurs in American institutions, including D. K. Yang, who would receive an RF Fellowship to study physics at the University of Chicago and Columbia University during 1926-1928.

Table 1: Physics faculty members at the Premedical School, PUMC, 1917-192550

\begin{tabular}{cc}
\hline Years of Service & Name \\
\hline 1917-1922 (Dept. Head, 1917-22; Dean 1918-22) & Stifler, William Warren \\
\hline $1917-1918$ & Tong, Yung-Tso \\
\hline $1919-1920$ & Ma, Ming-hsi \\
\hline $1919-1925$ & Stephenson, Bird R. \\
\hline $1920-1922$ & Kwei, Paul C. T. 桂质廷 \\
\hline $1922^{*}-1925$ (Dept. Head) & Corbett, Charles H. \\
\hline $1922-1925$ & Exner, Frank M. \\
\hline $1922-1925$ & Yang, David King** 杨菍卿 \\
\hline
\end{tabular}

In 1917, the PUMC established its own Premedical School because other schools in China were unable to supply qualified applicants with adequate scientific training. With the substantial, targeted support from the $\mathrm{CMB}$, the science departments at Yenching and other colleges and universities in China had made sufficient progress by the summer of 1925 to replace the primary function of the Premedical School. As a result, the board decided to close the School, and turned it over to Yenching in 1926, when the latter began the move from Beijing's southeast corner inside the city wall to the northwestern suburb five miles from the walled city, where a brand new and greatly expanded campus was laid out between the imperial Summer Palace and Tsinghua University. The merger, which included the transfer of the whole library and collection of equipment and apparatus of the School to Yenching University, provided further substantial impetus to the development of Yenching's Department of Physics (Edwards 1959, 161). ${ }^{51}$

50 Ferguson 1970, 243. * The year Corbett began his service at PUMC was listed as 1923 on page 243, probably by mistake. Since both Corbett and D. K. Yang appeared in the photo "The Premedical School: Faculty and Staff 1921-1922" in this volume and we know that Yang began his service in 1922, Corbett should have begun his service in 1922, which is also consistent with the statement in Edwards 1959, 161. ${ }^{* *}$ Ferguson's book misspelled Yang's name as "Yang, David Kinn."

51 The merger could have taken place as early as the summer of 1925 when the Premedical School was closed (Ferguson 1970, 39). For the transfer of the library and equipment, see Meng 1982, 653. 


\section{Charles Corbett and the beginning of physics education at Yenching}

Yenching University was born from the union of four missionary institutions around Beijing between 1915 and 1920. In descending order by size, these institutions were the Methodist Peking University; the North China Union College organized by the American Board of Commissioners for Foreign Missions (Congregational), the Presbyterian Mission, and the London Missionary Society; the North China Union College for Women (originally named the Bridgman Academy); and a union of the theological seminary of the North China Educational Union and two Methodist theological schools in Beijing (West 1976, 34-35). Officially founded in 1918,52 and led by the liberal President John Leighton Stuart (1876-1962) (Figure 3), a Chinese-born American missionary, Yenching University developed steadily after its foundation, both in size and in academic quality. Its enrollment in 1918 was 75, but by 1935, two years before the Japanese occupied Beijing and launched its full-scale invasion of China, the enrollment had reached 884 (including 274 women), increasing by a factor of almost 12 (Zhang, Wang, and Qian 2000, 1162, 1278). From 1925, Yenching already ranked among the top ten universities, both public and private, in China. ${ }^{53}$ By the mid-1930s, the Yenching faculty proudly found their students "consistently superior" to their American peers when judged by the contemporary American national standard for college level courses. ${ }^{54}$

Physics instruction was available at Yenching from the beginning because it existed in the university's constituent institutions. As we discussed in the previous section, such instruction at Yenching was first carried out in collaboration with the Premedical School of the PUMC. One founding faculty member of Yenching and the founder of its Department of Physics was Charles Hodge Corbett. Corbett, an American missionary,

52 Minutes of the General Faculty Executive Committee, Dec. 4, 1928, in 燕京大學行政委員會記 錄 (英文本) [(English) minutes of the general faculty executive committee at Yenching University], 1928.7-1929.6 (YJ28004, Yenching University Archives in Peking University Archives in Beijing, China), 134, GFE-1723.

53 A study at the University of California in the mid-1920s rated Yenching University "Class B," meaning that its graduates "might be permitted to enter graduate schools in the United States without deficiencies." Only one other mission college and eight government institutions in China received the same or higher rating. See Kuno 1928, 56; Lutz 1971, 202; Zhang, Wang, and Qian 2000, 16. In Kuno's ranking, the four top rated "Class A Universities" were Peiyang, Tang-Shan, and Tsing Hua universities and the College of Agriculture of the University of Nanking; following them were seven "Class B Universities": Conservancy (or Hohai) Engineering College, the Fourth National Chung-Shan (National Southeastern) University, Nanyang (The First Chiao-Tung) University, University of Hong Kong, University of Nanking, Yenching University, and the National University of Peking (Kuno 1928, 55-56).

54 William Band, "The China Colleges and Instruction in the Natural Sciences," in Archives of the United Board for Christian Higher Education in Asia, New File, RG 11, 64A-841 (New Haven, CT: Special Collections, Yale Divinity School Library, 1956), 12. 
was born in China to a Presbyterian missionary family from Pennsylvania, and had a good command of both spoken and written Chinese. At the age of fifteen, he went to America for the first time, where he received his college education. After graduating from the College of Wooster in 1901 and Union Theological Seminary in New York with his BD in 1907, he received a fellowship from the Rockefeller Foundation, and spent another year taking courses at Columbia University and the University of Chicago, before returning to China.

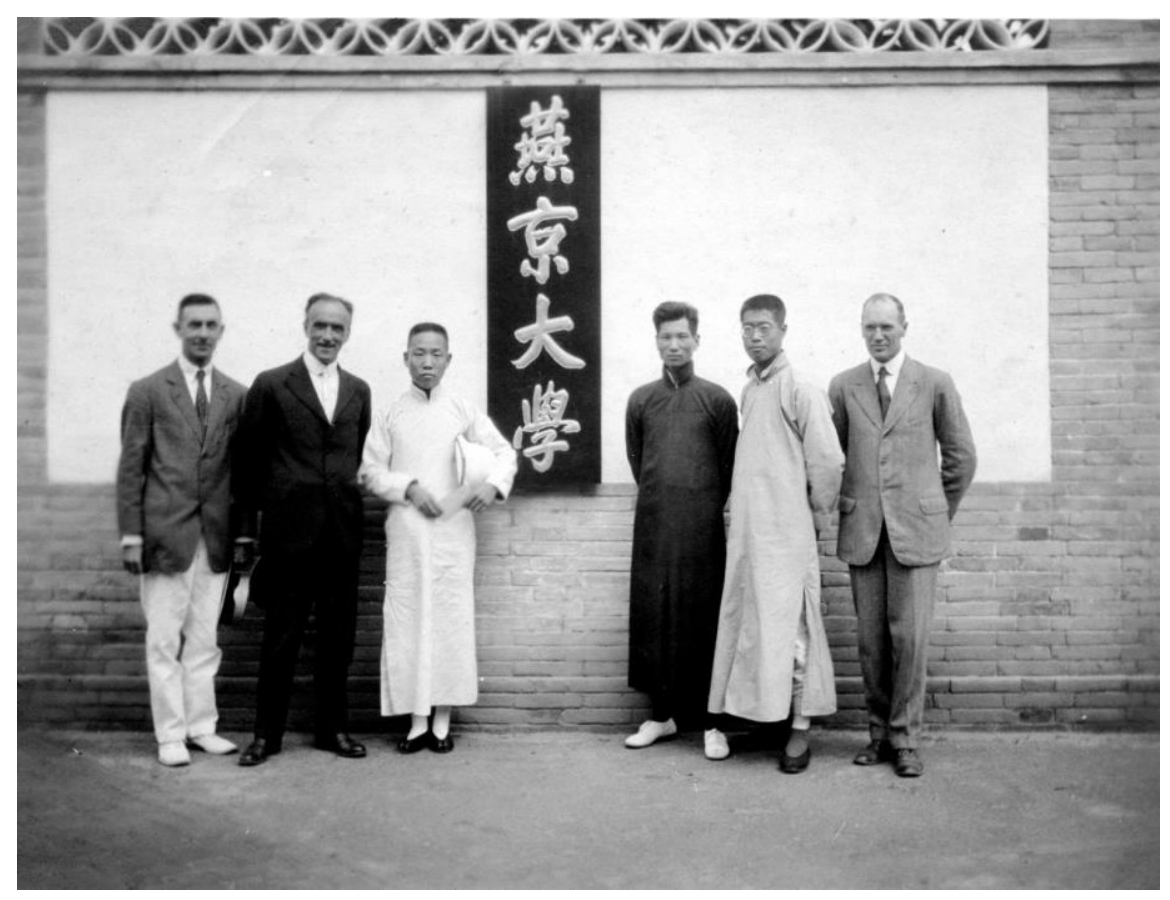

Figure 3: C. H. Corbett (far left) and J. L. Stuart (second from left) with colleagues in front of the new Chinese name board of Yenching University, likely soon after it was founded on Kuijiachang campus (Special Collections, Divinity Library, Yale University, the United Board for Christian Higher Education in Asia Records, RG 11, 421-0000-6017).

In 1908, Corbett joined the faculty of the North China Union College (NCUC) in Tongzhou, twelve miles east of Beijing (Figure 4). At the NCUC, Corbett taught science and was especially interested in teaching physics, "illustrated by every day objects in Chinese life-the carrying pole, the wheelbarrow, the tow boat and the like." $55 \mathrm{He}$ continued to devote himself to physics education even after becoming a leading executive of the newly organized Yenching University. Corbett was elected as Secretary

55 For Corbett's biographical data, see Smith and Corbett 1965, 73-78. The quote appears on page 74 . 
of the Board of Managers of the University in July 1920, and he helped John Leighton Stuart coin Yenching's famous motto: "Freedom through Truth for Service" (Stuart 1954, 75). ${ }^{56}$ On Stifler's departure in 1922, Corbett became the head of the Department of Physics of the Premedical School. In the following three years, Corbett concurrently chaired the physics departments both in the PUMC and at Yenching University (Edwards 1959, 161; Smith and Corbett 1965, 75). The PUMC Director, Henry S. Houghton, was very satisfied with Corbett's work. In 1924, he wrote to Greene, the CMB Director, praising Corbett as "one of our most successful teachers." To justify his tribute, Houghton added, "Dr. Stifler said of him on one occasion that Corbett was the only man he ever knew who could teach more physics than he actually knew. From one of Dr. Stifler's critical judgment in such matters, I consider this a very high compliment indeed." 57 Whether or not Stifler's remark on Corbett was genuinely complimentary, his observation clearly revealed Corbett's distinctive passion for physics teaching as well as his scientific limits.

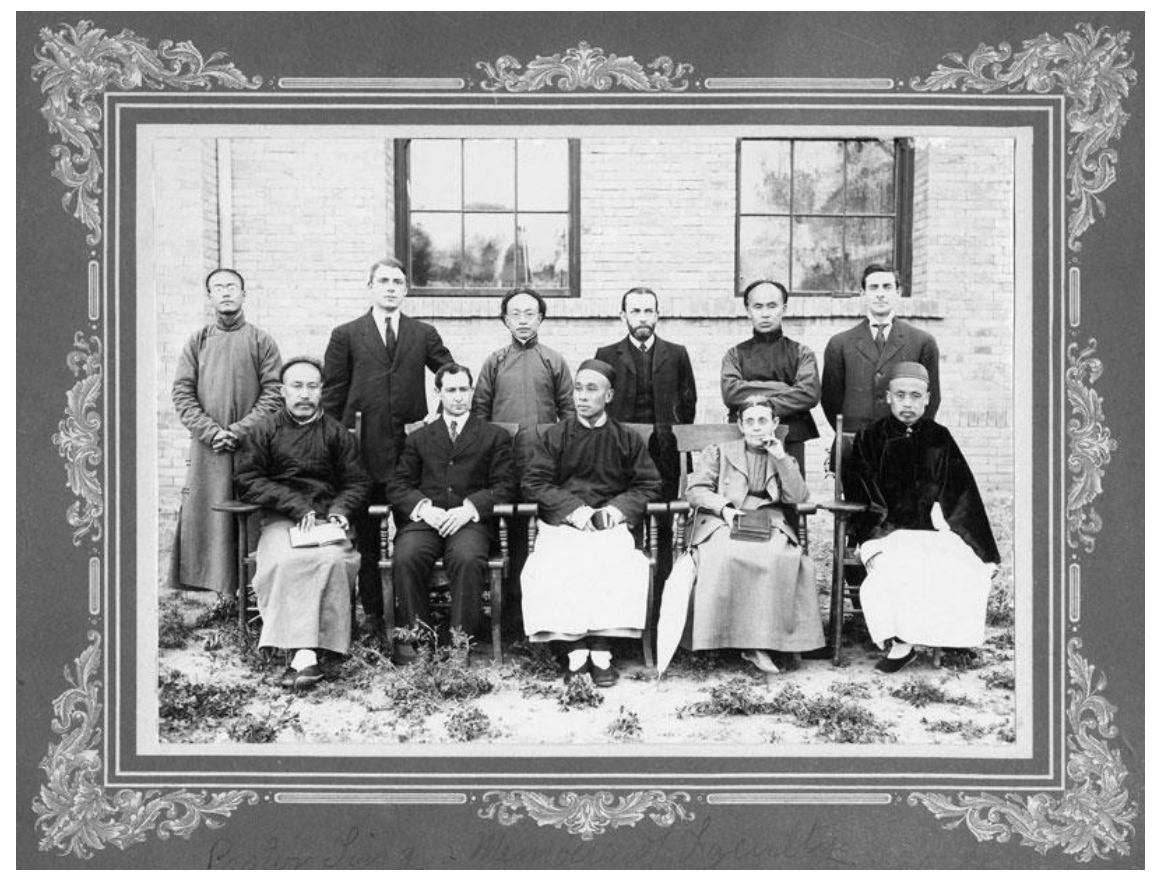

Figure 4: Faculty of North China Union College, Beijing, China, ca. 1910. Corbett is standing on the far right (YDS/RG008/087/0001/0003, Yale University. Divinity School. Day Missions Library).

56 Also see Archives of the United Board for Christian Higher Education in Asia, RG 11, 324-4957, Special Collections, Yale Divinity School Library, New Haven, CT.

57 Houghton to Greene, July 14, 1924, Folder 881 (Physics, 1921-1925), Box 121, RG IV2B9, CMB, Inc., Rockefeller Foundation records, Rockefeller Archive Center. 
As shown in Table 2, the Department of Physics at Yenching had its first graduate in 1922. In 1924, the department had a faculty of four: Corbett, Associate Professor and Head; Yu-Ming Hsieh 谢玉铭, Instructor (absent on leave and studying in America); Pao Ho Wang 王葆和, Assistant; and D. K. Yang, Honorary Instructor (Assistant, PUMC). ${ }^{58}$

Table 2: Early physics graduates of Yenching University ${ }^{59}$

\begin{tabular}{|c|c|c|c|c|c|c|c|}
\hline 1922 & 1923 & 1924 & 1925 & 1926 & 1927 & 1928 & 1929 \\
\hline \multicolumn{8}{|c|}{ Bachelor of Science (BS) } \\
\hline \multirow[t]{2}{*}{$\begin{array}{l}\text { Ming-Hsien Li } \\
\text { 李明显 }\end{array}$} & & $\begin{array}{c}\text { Pao-Ho Wang } \\
\text { 王葆和 }\end{array}$ & & $\begin{array}{l}\text { Mao-Ling Liu } \\
\text { 刘茂龄 }\end{array}$ & $\begin{array}{l}\text { Pei-Hsiu Wei } \\
\text { 魏培修 }\end{array}$ & $\begin{array}{c}\text { Chao-Ying Meng } \\
\text { 孟昭英 }\end{array}$ & $\begin{array}{l}\text { Chieh-San Liu } \\
\text { 刘捷三 }\end{array}$ \\
\hline & & & & & $\begin{array}{l}\text { Ching-Huan Wu } \\
\text { 吴敬寰 }\end{array}$ & $\begin{array}{l}\text { Chin-Tuo Wu } \\
\text { 武金铎 }\end{array}$ & $\begin{array}{c}\text { Ssu-I Wang } \\
\text { 王思义 }\end{array}$ \\
\hline \multicolumn{8}{|c|}{ Master of Science (MS) } \\
\hline \multicolumn{8}{|r|}{ Pei-Hsiu Wei } \\
\hline \multicolumn{8}{|r|}{ Ching-Huan $\mathrm{Wu}$} \\
\hline
\end{tabular}

Between 1925 and 1926, the department not only underwent a great transformation as a result of its merger with the Premedical School department, but also witnessed a sudden leadership change due to Corbett's unexpected resignation. In summer 1925, Corbett returned to America on furlough, which was at least one year overdue; a few months later, however, he unexpectedly resigned from both the university and his mission in January 1926. He was determined to leave despite the effort of both President Stuart and the mission to retain him. In his letter of resignation to Eric M. North, the Executive Secretary of the Board of Trustees of Peking (Yenching) University in New York, Corbett argued,

I feel that Peking University must have the best teachers available in Christendom and to have me at the head of the Physics Department is to fall far short of the possibilities of that position. I have worked as hard as I could, but I know my limitations, and though my friends in Peking still are kind enough to want me back, I think they will realise

58 Yenching University, Peking University (Yenching Ta Hsueh) Bulletin: Colleges of Arts and Sciences Announcement of Courses, 1924-1925, Vol. VI (No. 21) (Yenching University Archives in Peking University Archives in Beijing, China), 36.

59 This table is the result of my study of the following: 燕大理學院校友消息 [Yanda's School of Natural Sciences alumni news] (1935) (YJ 1935011, Yenching University Archives in Peking University Archives in Beijing, China), 15-16; “Alumni Address" 1940, 22. Yenching University Bulletin, Directory of Faculty and Students in relevant years; and Chieh-san Liu's thesis deposited at Peking University Library. It has been previously claimed that Miss Chou Chi-yun 周启运 earned her BS in this department in 1925 (see Pan, Wu, and Fan 1993, 494), but her BS was actually in mathematics (see the "Alumni news" above, 18). 
before long that I have acted wisely. ${ }^{60}$

This was an issue Corbett had actually pondered for a long time. He had informed both Greene and Stuart no later than July 1924 that "in case a man should be found with a training more complete than his own, [he] would be glad to step aside in his favor, regardless of whether the new appointee had had a wider teaching experience." Upon learning of Corbett's proposal, Houghton stated that it was "certainly a most generous thing" for Corbett to do. ${ }^{61}$

In another letter to the Trustees of Peking (Yenching) University, Corbett further elaborated on his resignation,

I have long felt that the positions in the University should be filled by Chinese as soon as possible. For this reason[,] I have taken steps to help my Chinese colleagues get an adequate training, partly by tutoring them myself and partly by securing opportunities for them to study abroad. Mr. Y. M. Hsieh is now spending his third year of graduate study in America and will be ready to return to China next autumn, at which time Mr. D. K. Yang will probably come to America for study, on a fellowship granted by the China Medical Board. Both these men are members of our staff, have had several years of teaching experience, and are Christians of strong conviction. You may not feel that either of these men is ready to be placed at the head of the department, but the University has in Dr. Paul Anderson a well-trained physicist, who is making a good record in Peking, and who can give stability to the department in this time of transition. I have tried to lay a good foundation, but I feel that I have done as much as a man can do, who did not plan to be a physicist. Progress will be more rapid under the younger and better trained men.62

In his private correspondence with a close friend, Corbett disclosed three more grounds for his decision. Top among them was his profound disappointment at "the theological situation in the [Presbyterian] Church":63

I have tried to avoid controversy and have used my influence to maintain fellowship between liberals and conservatives, with a fair amount of success. But the burden of it has been heavy, [and] I had to meet the brunt of the Fundamentalist attack last year and came near to a nervous breakdown as a result. The vast majority of the Mission can never

60 Charles H. Corbett to Eric M. North, January 8, 1926. Brooklyn, New York. Special Collections, Divinity Library, Yale University, the United Board for Christian Higher Education in Asia Records, RG 11, 324-4957. Reactions of Stuart and the Mission to Corbett's resignation: Smith and Corbett, 75 .

61 Houghton to Greene, July 14, 1924, RF Records, RAC.

62 Corbett to the Trustees of Peking (Yenching) University, Brooklyn, New York, January 8, 1926. Special Collections, Divinity Library, Yale University, the United Board for Christian Higher Education in Asia Records, RG 11, 324-4957.

63 This was likely impact from the "Fundamentalist-Modernist controversy." See van der Wall 2007, 3-6. 
become reconciled to the liberal attitude of the theological college of the University. The burden of trying to keep working with people who absolutely refuse to budge, who will not read and will not study, and yet feel themselves perfectly competent to express a judgment on theological questions, is killing. It seems futile to spend one's life trying to establish a church in China which persists in being dogmatic and obscurantist.

Moreover, Corbett was concerned about his job security at Yenching in the next decade, and wished to "strike out on some other line" while he was in his forties instead of fifties. As a result of "the growing nationalist spirit of the Chinese," he believed that "it is desirable that the church and our Christian institutions should lose their foreign aspect as soon as possible," which also convinced him that "there is no future for a white man [like himself] in this institution." Thirdly, as the secretary of the Board of Managers of Yenching University, which he was elected "much against [his] wishes" in summer 1920, Corbett was deeply frustrated by the way the University was rapidly changing, which, in his opinion, had become "an institution that flourishes on sentiment" and was "organized in the most intricate and ineffective way possible." He also felt isolated among the majority of his Yenching colleagues, "an effervescent and delirious group of amiable but impractical enthusiasts" who "rush[ed] around with a great deal of activity and very little accomplishment, with lots of talk and gush, but a general aversion to routine." He blamed these people for "constantly pushing the University out into new activities for which it is not prepared," and then "straightway rush[ing] off to find some new adventure, leaving men like myself to toil and slave to keep us from disaster." 64

It is clear that Corbett's decision was influenced by the anti-Christian and "Restore Educational Rights" movements in China in 1925. Being neither a Fundamentalist nor a Liberal, Corbett had attempted to reconcile the two groups to no avail. He resented the "brunt" he suffered from the Fundamentalist attack, but was also reluctant to go along with the Liberals, including, perhaps, President Stuart, on the direction in which the university was heading. Born in China, Corbett knew the Chinese language and customs well and had "a host of friends" there. He genuinely supported his Chinese colleagues like Hsieh and Yang, and was devoted to the development of their department. Corbett's ultimate and true passion, however, lay in advancing the evangelical mission rather than the study of physics, and he was clearly aware of his limitations in the subject. When Yenching University had begun a decisive transformation, and was on its way to become "one of the outstanding scientific centers

64 Smith and Corbett 1965, 75-76. Corbett elected as the Secretary of the Board of Manager: Charles H. Corbett to Eric M. North, July 16, 1920. Peking, China. Special Collections, Divinity Library, Yale University, the United Board for Christian Higher Education in Asia Records, RG $11,324-4957$. 
in China," Corbett made an appropriate career choice for himself. ${ }^{65}$

\section{Paul Anderson and the inauguration of the Master of Science Program}

In its early years, the Department of Physics at Yenching, with the main mission of preparing premedical students for PUMC, had very low enrollment. It was not until 1922 that the department produced its first Bachelor of Science (BS), as shown in Table 2. Enrollment remained low in the 1920s. Between 1922 and 1929, a total of only nine students received their BS degrees in physics at Yenching. By the end of this period, however, two Yenching students had graduated from the department's Master of Science (MS) Program, becoming the first MS graduates in physics in China. This development also reflected a significant transformation in the department. The starting point for this transformation was the arrival from Harvard University of a new faculty member in mid-1925.

Born in Chicago on November 26, 1897, Paul Alexander Anderson (1898-1990) (Figure 5) earned his Bachelor degree at the University of Illinois in 1920. He then spent one academic year (September 1920-June 1921) at University College London before going to Harvard University in fall 1921. While studying at Harvard, Anderson also began to work at Eastman Kodak Company Research Laboratory in July 1923. In June 1925, he received his PhD in physical chemistry at Harvard, supervised by Theodore W. Richards, winner of the Nobel Prize in Chemistry in 1914. Upon receiving his doctorate, Anderson left Eastman Kodak Company in July and accepted the joint appointment of Yenching University and the CMB. Arriving at Yenching with his wife in summer 1925, Anderson was initially appointed as an "Instructor in Physics" and "Acting Head" of the Department of Physics.

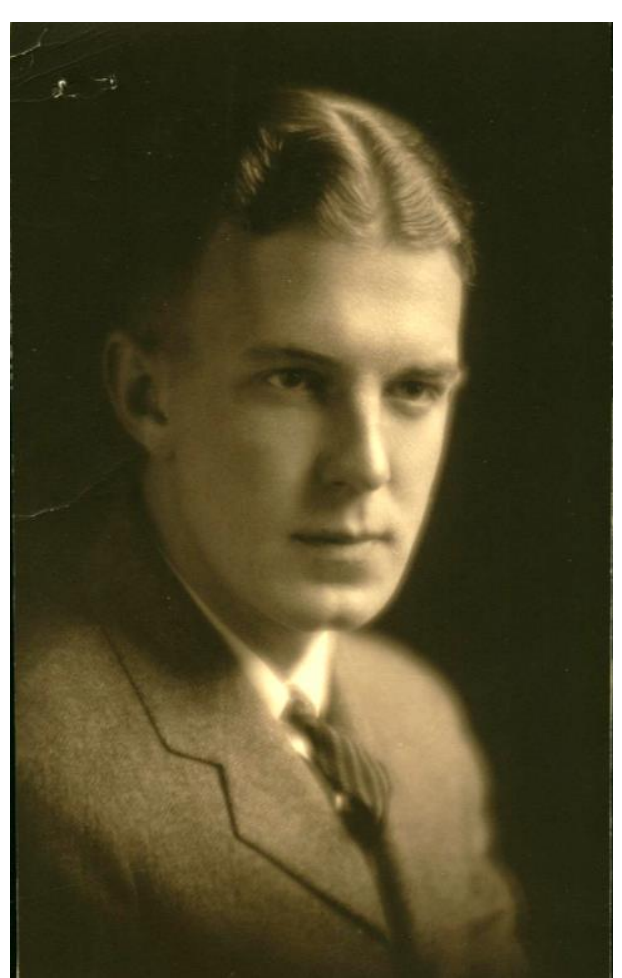

Figure 5: Paul A. Anderson in 1924 (Special Collections, Divinity Library, Yale University, the United Board for Christian Higher Education in Asia Records, RG 11, 421-5927, 7201).

65 After 1926, Yenching University quickly became a scientific center in the country: Edwards 1959, 161. 
Within two years, however, he became the department's full "Chairman." 66

The story of how Yenching and the CMB recruited this fresh Harvard doctorate is rather remarkable. Over the summer of 1924, the PUMC and the CMB became increasingly anxious about the effectiveness and continuity in physics instruction (delivered to students from both the PUMC Premedical School and Yenching) over the coming years, especially after the school year of 1924-1925. Exner would leave China in summer 1925 after completing his three-year appointment. That same summer, Corbett, who was heading up both physics departments concurrently, was also scheduled to return to America on furlough. The departure of both Corbett and Exner would have left both departments in jeopardy if there were no appropriate replacement on the faculty for 1925-1926. More importantly, the entire Premedical School was going to be transferred in the summer of 1925 to Yenching University on the latter's brand-new campus (Figures 6-7). It was clearly in the interest of both the PUMC and Yenching to have an able and experienced leader to implement the planned transition and carry on physics instruction at Yenching. ${ }^{67}$

Earlier in 1924, the CMB and Yenching had searched fruitlessly for months for a new physics instructor willing to serve in China for several years. ${ }^{68}$ Someone in the CMB thus proposed to put off Corbett's furlough again because he had spent eight months in Chicago in 1922. Houghton, however, firmly opposed the idea, arguing convincingly that:

It is not feasible to defer Mr. Corbett's furlough because his health is seriously below par at the present time, and his furlough is already a year over due. It is true that he had a leave of absence for study in Chicago, but that was scarcely a rest since he was working at high pressure all the time he was away. His physical condition has given us a good

66 For sources of Anderson's biographical data, see: NAS Archives, NRC Rockefeller Fellowships, Fellowship Applications, Paul Alexander Anderson (1929-31. Deposited at National Academy of Sciences, Washington, DC, US). Cheryl Gunselman, the manuscripts librarian at Manuscripts, Archives, and Special Collections Washington State University Libraries, e-mail message to author, 4 August 2016; National Research Council (US) 1944, 25; Zearott 2013-2014, 22-25. Anderson's dissertation was titled "I. The Electrochemical Behavior of liquid barium amalgams. II. The activity of hydrogen desorbed from platinum and palladium" (http://id.lib.harvard.edu/aleph/003739931/catalog, accessed August 1, 2016). Anderson's appointment at Yenching: Yenching University Bulletin, Colleges of Arts and Sciences: Announcement of Courses, 1925-26, Vol. VII (No. 21), Peking, China, May 1925 (Yenching University Archives in Peking University Archives in Beijing, China), 46; Yenching University Bulletin, Announcement of Courses, 1927-28, Vol. X (No. 21), Peking, China, September 1927 (Yenching University Archives in Peking University Archives in Beijing, China), 54; Pan, Wu, and Fan 1993, 494.

67 Houghton to Greene, July 31, 1924, Excerpt, Folder 881 (Physics, 1921-1925), Box 121, RG IV2B9, CMB, Inc., Rockefeller Foundation records, Rockefeller Archive Center; Houghton to Greene, August 11, 1924, Folder 881 (Physics, 1921-1925), Box 121, RG IV2B9, CMB, Inc., Rockefeller Foundation records, Rockefeller Archive Center.

68 Houghton to Greene, July 31, 1924, Excerpt, RF Records, RAC. 
deal of concern and his physicians insist that he should begin his furlough next spring without fail. 69

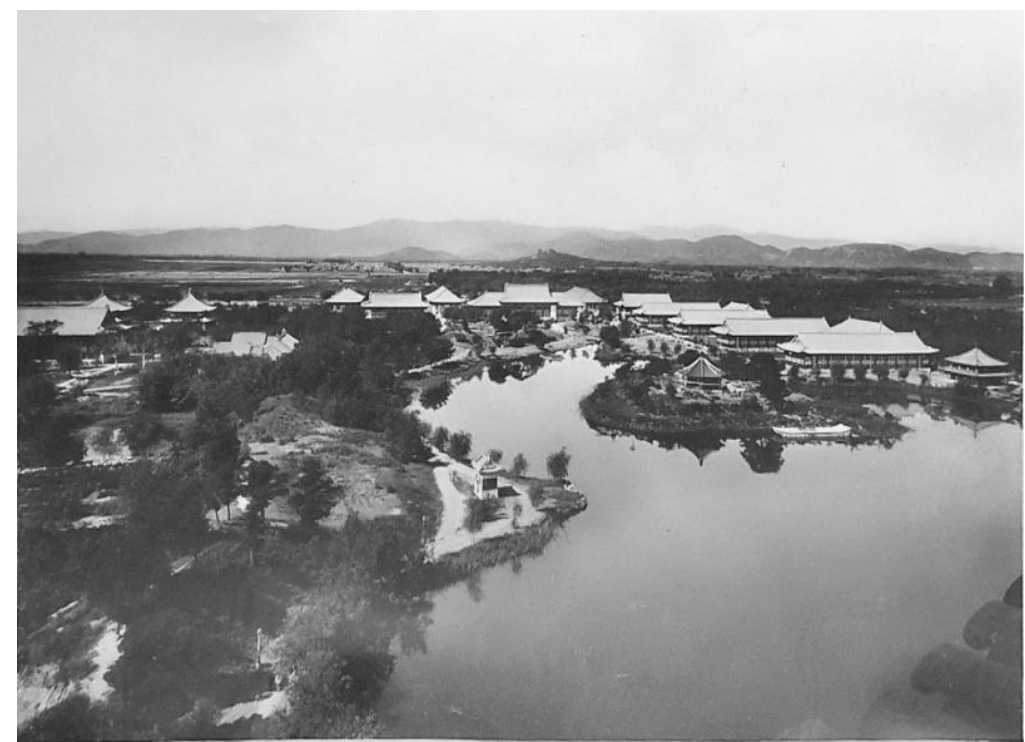

Figure 6: A general view of the new campus of Yenching University (Yenching University, Box C3, Series 601 China, Photographs, Rockefeller Foundation records, Rockefeller Archive Center).

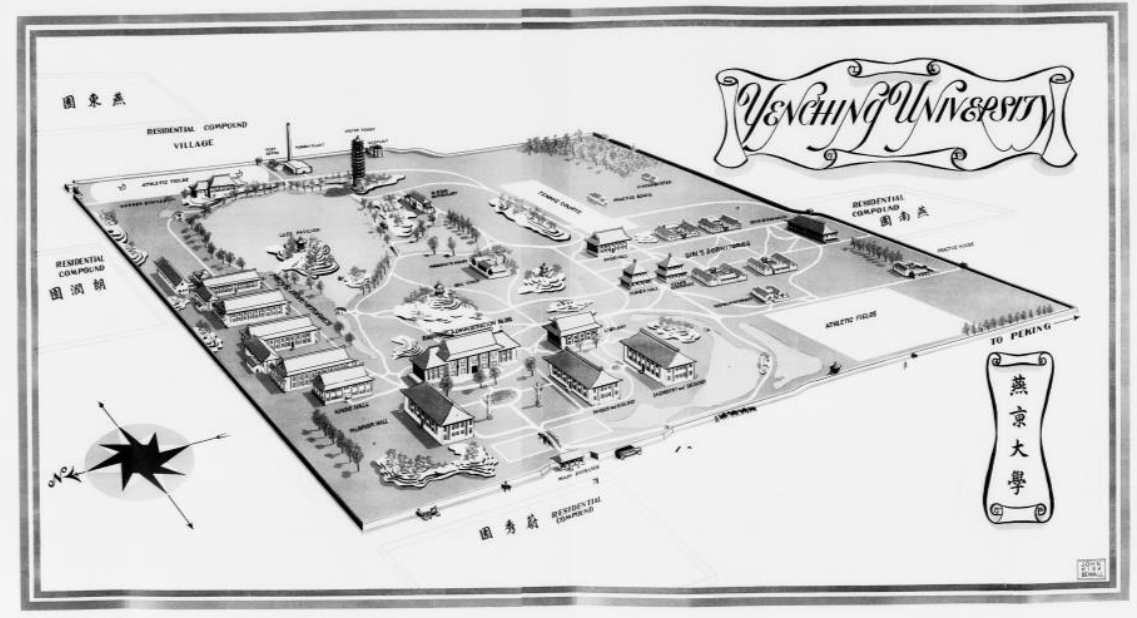

Figure 7: A map of Yenching University new campus (Special Collections, Divinity Library, Yale University, the United Board for Christian Higher Education in Asia Records, RG 11, 307-4743).

69 Houghton to Greene, August 11, 1924. RF Records, RAC. 
Failing to attract anyone to come to China for longer service, the CMB turned to consider hiring someone with only a one-year appointment in July. However, all department heads in the Premedical School, that is, Aura E. Severinghaus (biology), Stanley D. Wilson (dean and chemistry), and Corbett (physics), "strongly advised against the appointment of a man for a single year." Instead, they "were rather insistent" on having "someone who would carry the work over into Yenching." To help achieve this, all three men "willingly assumed the responsibility" for maintaining the work in the physics department in 1924-1925 so that the CMB could have additional time to secure an ideal man for the position, and Corbett even volunteered to increase his teaching hours "very considerably" despite his poor health. ${ }^{70}$ Unwilling to overburden Corbett, Houghton arranged for the hiring of an electrical engineer at the PUMC as a part-time instructor to teach "electro-physics" for a year, and meanwhile to increase Exner's teaching responsibility, which solved the problem for 1924-1925.71 Finding a long-term physics instructor for 1925-1926 and beyond was, however, much more challenging, partly because it was Yenching, not the $\mathrm{CMB}$, that took the initiative in this search. This was because the person employed was expected to remain at Yenching not the PUMC. Hence, the CMB "never sent broad-cast requests to the heads of departments at different institutions" as they used to do. Instead, the board only inquired of "various persons more or less connected with the organization." 72

Anderson had no previous connection with either Yenching or the CMB. Yenching learned about his possible availability only because of Miss Marion Parker Perrin, a graduate of Wellesley College, who was an Instructor in History at Yenching in 1923-1924 (Figure 8). ${ }^{73}$ Before Perrin returned to America in 1924 to marry Anderson,

70 Houghton to Greene, July 31, 1924, Excerpt, RF Records, RAC. There was another "Severinghaus," Leslie R. Severinghaus, on the faculty of the Premedical School's Department of Modern European Languages. Houghton did not identify in his letter which Severinghaus he meant, but based on the purpose of their discussion and the background of other participants, it is reasonable to believe that it was Aura E. Severinghaus, head of the Department of Biology of the Premedical School. In hindsight, Corbett's demand to hire someone with a long-term commitment might also be an indication of his intention to leave Yenching, as discussed earlier. 71 Houghton to Greene, September 25, 1924, Folder 881 (Physics, 1921-1925), Box 121, RG IV2B9, CMB, Inc., Rockefeller Foundation records, Rockefeller Archive Center. The electrical engineer was Caryl H. Bovell (Foreign Missions Conference of North America and Boynton, 1927, Supplemental Cable Code, 3).

72 Eggleston to Vincent, August 28, 1924, Folder 881 (Physics, 1921-1925), Box 121, RG IV2B9, $\mathrm{CMB}$, Inc., Rockefeller Foundation records, Rockefeller Archive Center.

73 On Marion P. Perrin: Wellesley College 1922, 146; Peking University (Yenching Ta Hsueh) 燕 京大學 Bulletin, No. 21, Announcement of Courses, 1923-1924 (Special Collections, Divinity Library, Yale University, the United Board for Christian Higher Education in Asia Records, RG 11, 308-4744), 21. Please note that in this bulletin, Marion P. Perrin's first name was is misspelled as "Marian." Marion P. Perrin's portrait, November 1921. Special Collections, Divinity Library, Yale University, the United Board for Christian Higher Education in Asia Records, RG 11, 421-5929, 7287. See the notes on the back of the portrait. Perrin appeared to have begun her teaching at Yenching as early as 1922. 
she had "expressed a determination" to President Stuart that she would return "within the next year or two."

Informed by Stuart that Perrin's influence might bring Anderson to China, Houghton suggested Anderson to the CMB in mid-August 1924, wondering about his availability. At the same time, however, Houghton was clearly uncomfortable about letting Anderson, "a man without any teaching experience," take charge of the department while Corbett was absent. For Houghton, Anderson was "the least desirable of the three possibilities" available then, but might also be "the only way out" eventually. ${ }^{74}$

Corbett and Wilson were even more anxious than Houghton about having Anderson. Even after Houghton was prepared to accept Figure 8: Marion P. Perrin in 1921 Anderson one month later, Corbett and Wilson (Special Collections, Divinity Library, were still "somewhat reluctant" to let him "take Yale University, the United Board for the entire responsibility for carrying on the Christian Higher Education in Asia department," because he not only had no Records, RG 11, 421-5929, 7287). teaching experience but also was "entirely new to conditions in China." 75 However, nobody other than Anderson eventually accepted the appointment at Yenching, and he agreed to come to Beijing in 1925 instead of 1926, as Houghton had previously expected. ${ }^{76}$ Clearly Marion Perrin's influence on Anderson was considerable.

Despite such earlier doubts, Anderson, this inexperienced teacher and stranger to China, did quite well in 1925. Even Corbett praised Anderson for making "a good record" in Beijing. ${ }^{77}$ Just as Corbett had predicted in early 1926, "Progress [in the department] will be more rapid under the younger and better trained men." 78 Under Anderson's leadership, the department began to reform. Along with other science departments in the university, the Department of Physics also attempted "to extend its scientific work beyond the premedical level, offering additional courses and engaging in important research" (Edwards 1959, 161). Anderson expanded Yenching's physics curricula with new courses, such as thermodynamics, advanced electricity and

74 Houghton to Greene, August 11, 1924. RF Records, RAC.

75 Houghton to Greene, Sept. 25, 1924, RF Records, RAC.

76 Houghton to Greene, August 11, 1924. RF Records, RAC.

77 Corbett to Peking University Trustees, January 8, 1926.

78 Ibid. 
magnetism, direct-current electrical measurements, mathematical methods in physics, and modern developments in physics. ${ }^{79}$

Anderson was a passionate practitioner and promoter of physics research, who believed that research was not merely "part of the graduate training process," but also "a normal activity for any trained physicist or physics professor" (Zearott 2013-2014, 24). Under Anderson's leadership, the department began to raise the bar for the BS degree in physics, stressing "original investigation." In order to receive the BS degree, Anderson decreed that students not only should earn a certain number of credits in physics, mathematics, chemistry, and sociology, but also must complete a thesis that comprised "a simple original investigation and the preparation of a bibliography and historical resume of previous work in the field, with practice in the use of the original literature." 80 Matching the new requirement, during the 1926-27 academic year Anderson initiated a new course, "Senior Thesis," which was required for undergraduate students electing physics as their major. In this course, Anderson encouraged students to prepare "[a] historical and critical resume of some branch of physics, a careful redetermination of an important constant, or a simple original investigation, as decided in conference with the staff." 81

In 1927, Anderson established a Master of Science Program in physics, the very first such program in the country (Sun 2006, 476, footnote (1); Pan, Wu, and Fan 1993, 494; Dong 2009, 5). ${ }^{82}$ To earn this new MS degree at Yenching, the students had to demonstrate their "ability in original investigation." This ability was "construed as including: (1) a thorough understanding of the method fundamental to all scientific research; (2) the necessary command of experimental technique, and especially (3) initiative in carrying forward a problem without the detailed direction of the instructor. The ability to translate scientific German at a practicable rate is also required." 83 To help students meet the new requirements, he offered a further new course, "Graduate Research," with two objectives: to direct "graduate students with the necessary training" to "undertake original work," utilizing the department's facilities of equipment;

79 Yenching University Bulletin, Announcement of Courses, 1927-28, Vol. X (No. 21), Peking, China, September 1927 (Special Collections, Divinity Library, Yale University, the United Board for Christian Higher Education in Asia Records, RG 11, 308-4745), 55.

80 Ibid, "Curricula," $x$-xi.

81 Yenching University Bulletin: Announcement of Courses, 1926-27, Vol. IX (No. 21), Peking, China, March 1927 (Yenching University Archives in Peking University Archives in Beijing, China), 44 .

82 Among twelve universities that had established graduate programs by 1936, only three, Yenching, Tsinghua, and Peking, had a program in physics. As clearly shown in Table 6, Yenching's MS program was set up before the other two.

83 Yenching University Bulletin, Announcement of Courses, 1927-28, Vol. X (No. 21), Peking, China, September 1927 (Special Collections, Divinity Library, Yale University, The United Board for Christian Higher Education in Asia Records, RG 11, 308-4745), "Curricula," xi. 
and "to teach the fundamentals of method and technique" to those without research experience. ${ }^{84}$ Anderson's first graduate student, Pei-hsiu Wei, earned his master's degree in 1929 with a thesis titled "Chemical Decomposition of Silver Oxide by Slow Electrons," in which Wei attempted to determine the critical electron velocity or energy for decomposition of silver oxide film. Anderson suggested the problem to Wei and recommended the method used in this thesis (Dong 2009, 5; Wei 1929, 1, 22, 23). ${ }^{85}$

Anderson particularly valued the place of experiments in physics education. Such special appreciation of experiments later became a characteristic feature of the department. He worked hard to improve its laboratories, making many experimental instruments himself, for instruction as well as research. One of his contributions of long-lasting impact was the machine shop he established there, which was probably the first of its kind in the country. He also trained two mechanics for metalwork and woodwork respectively (Pan, Wu, and Fan 1993, 494) (Figure 9). ${ }^{86}$

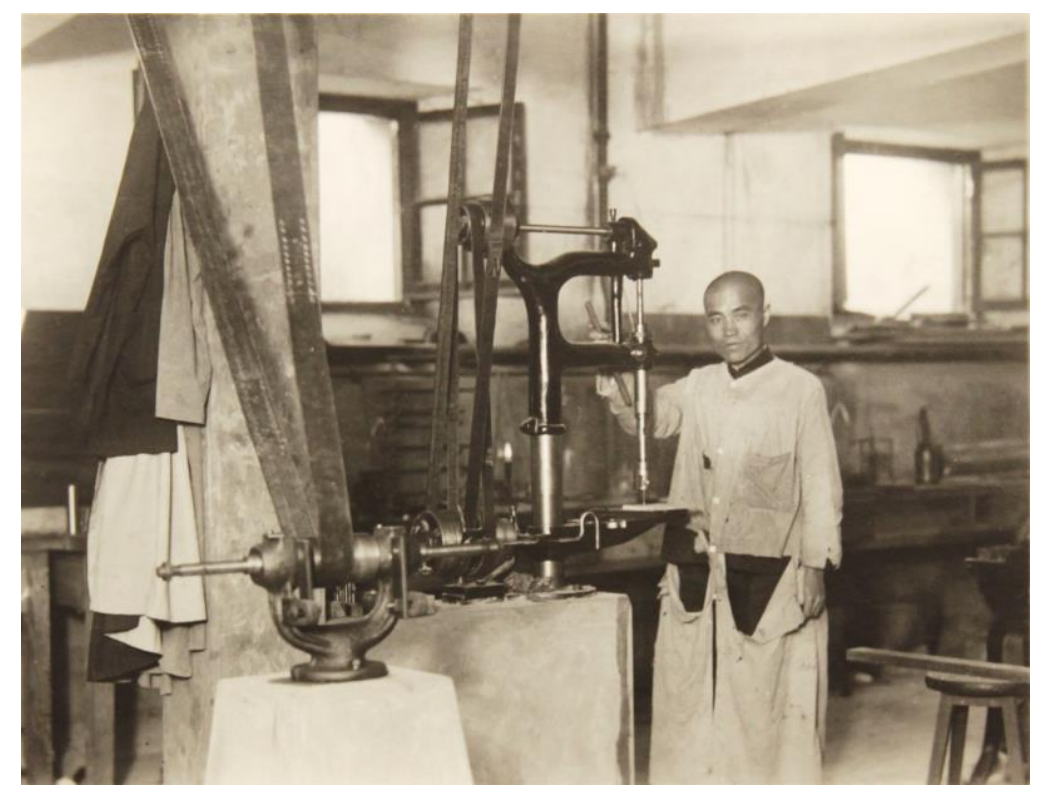

Figure 9: A mechanic in the machine shop of Yenching Department of Physics, 1929 (Yenching University, Folder 2708, Box 144, Series 601: China, RF [FA 003], Rockefeller Archive Center).

84 Ibid., 56.

85 Also see Yenching University College of Natural Sciences, Statement Presented to the Rockefeller Foundation, October 1929, in Archives of the United Board for Christian Higher Education in Asia, RG 11, 64A-843 (deposited in New Haven, CT: Special Collections, Yale Divinity School Library, 1929), 55.

86 Quotes about the training of mechanics: J. B. Tayler to W. Band, Peking, March 14, 1929. Records of the Council for World Mission, Box 27, Folder 2073, London Missionary Society Archives at School of Oriental and African Studies Library, University of London in London, UK. 
In addition to his administrative work, lectures, and responsibility for supervising students' theses, Anderson carried out his own experimental investigations, studying the purification of barium, which demonstrated his distinguished manipulative skill and brought advanced apparatus to the department. In January 1928, he published his research results in a paper titled "The Electromotive Behaviour of Single Metal Crystals" in Nature (Pan, Wu, and Fan 1993, 494). ${ }^{87}$

Just as the department was improving its quality in teaching and research under Anderson's leadership, he unexpectedly resigned from the chairmanship in September 1928. This was because his wife, Marion Perrin, died suddenly, most likely in child-birth, leaving him an infant boy to take care of. ${ }^{88}$ Nevertheless, he seems to have continued to teach at Yenching in fall 1928, since his salary arrangements there did not cease until the end of January 1929, probably because it was too late to cancel his scheduled courses (Figure 10). ${ }^{89}$

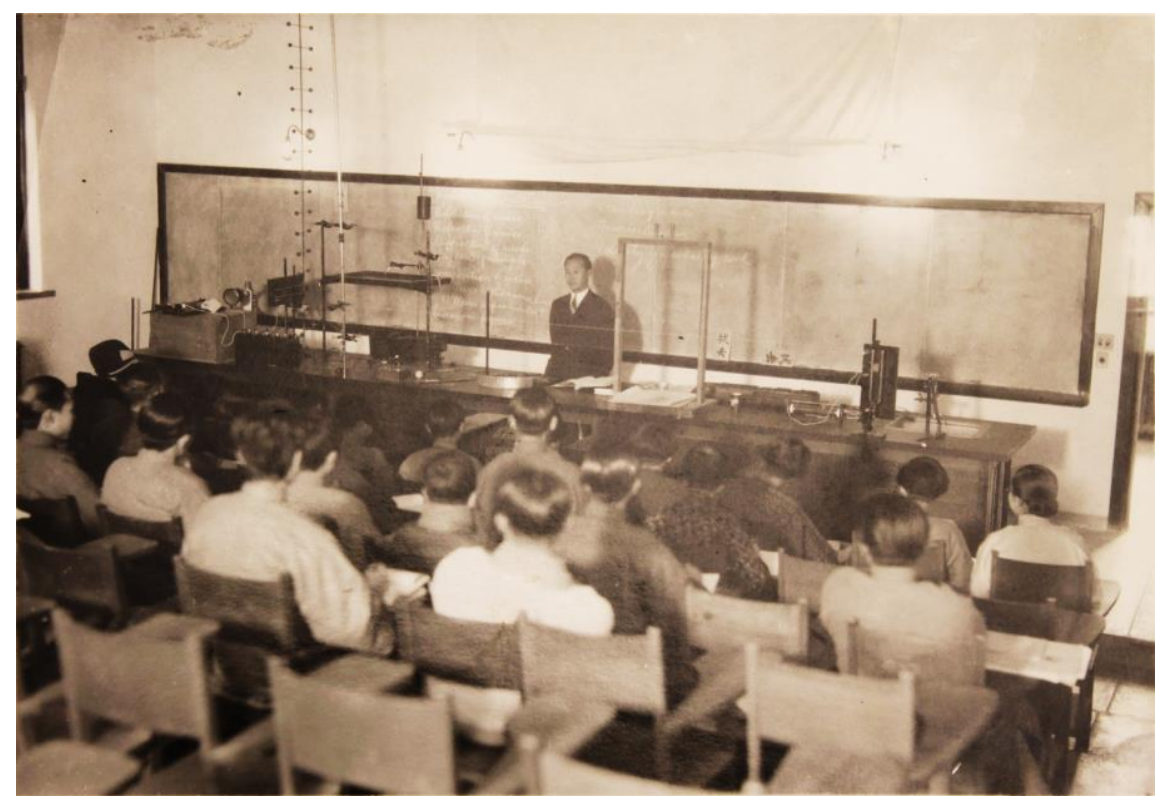

Figure 10: D. K. Yang and students in a lecture room at Yenching, 1929 (Yenching University, Folder 2708, Box 144, Series 601: China, RF (FA 003), Rockefeller Archive Center).

87 Quotes about Anderson's experimental research at Yenching: Ibid. Anderson's 1928 paper: Anderson 1928, 49.

88 NAS Archives. Anderson's son was born in either August or early September 1928. For Mrs. Anderson, née Marion Parker Perrin, see relevant discussion earlier in this section.

$89 \mathrm{Ibid}$. Anderson had been scheduled to teach five courses in the 1928-29 academic year; see 燕 京大學本科課程一覽, 第十一屆, 佈告第二十一號, 民國十七年 [Announcement of Courses for Undergraduate College, Vol. XI, No. 21, 1928], 1928-1929 (Yenching University Archives in Peking University Archives in Beijing, China), 47-52. 
Anderson had returned to America by the beginning of 1929. On January 6, he filed an application from Harvard University for the prestigious American National Research Fellowships (NRF) in Physics, Chemistry, and Mathematics, with Professors F. G. Donnan of University College London and P. W. Bridgman of Harvard University as his references. In his application, Anderson proposed "to carry further [at Harvard] . . . the study of the electromotive characteristics of single metal crystals," which he had "carried on at Peking during the [previous] year and a half." By the end of that month he had been awarded the annual fellowship, which was later renewed twice, eventually extending the normal twelve-month NRF tenure to an extraordinary twenty-eight months (February 1929-June 1931). ${ }^{90}$ While the success of Anderson's application for the NRF also reveals the significance of his investigation at Yenching, the repeated extensions of his NRF clearly attests to Anderson's eminence as a young American researcher.

Upon the completion of his NRF in the summer of 1931, Anderson accepted an appointment at Washington State College in Pullman, Washington, where from September 1931 he chaired the Department of Physics for the next thirty years (Zearott 2013-2014, 24). ${ }^{91}$ During the 1930s he had two distinguished accomplishments: he was the first investigator to achieve ultra-high vacuum conditions ( $\mathrm{P}<10-11$ Torr), which was so extraordinary that it "could not be measured or reached by other laboratories for 20 years;" he also constructed the first electron microscope outside of Germany. ${ }^{92}$ Anderson's post-1929 accomplishments demonstrate that he was not only an extraordinarily skillful experimentalist, but also an adept administrator, well-liked by his colleagues. One cannot help wondering how much more he might have done for the development of Yenching's Department of Physics had he stayed longer there. More than half a century after Anderson's departure from China, Meng, now a prominent Chinese physicist, still vividly remembered Anderson as "a knowledgeable physicist who actively initiated and promoted extracurricular scientific investigations, shepherding and supervising students' thesis work based on research" (Meng 1982, 653).

90 NAS Archives.

91 Also see National Research Council Questionnaire in ibid.

92 In his attempts to measure the "work functions" - the energy required to release an electron from the surface of a metal-of metals in the early 1930s, Anderson achieved the ultra-high vacuum conditions. See Donaldson and Dickinson, 1998. The quote appears in Zearott 2013-2014, 24. Working with Kenneth Fitzsimmons at WSC in 1935, Anderson constructed this early electron microscope. See “A Story of Two Washingtons" 2003. 


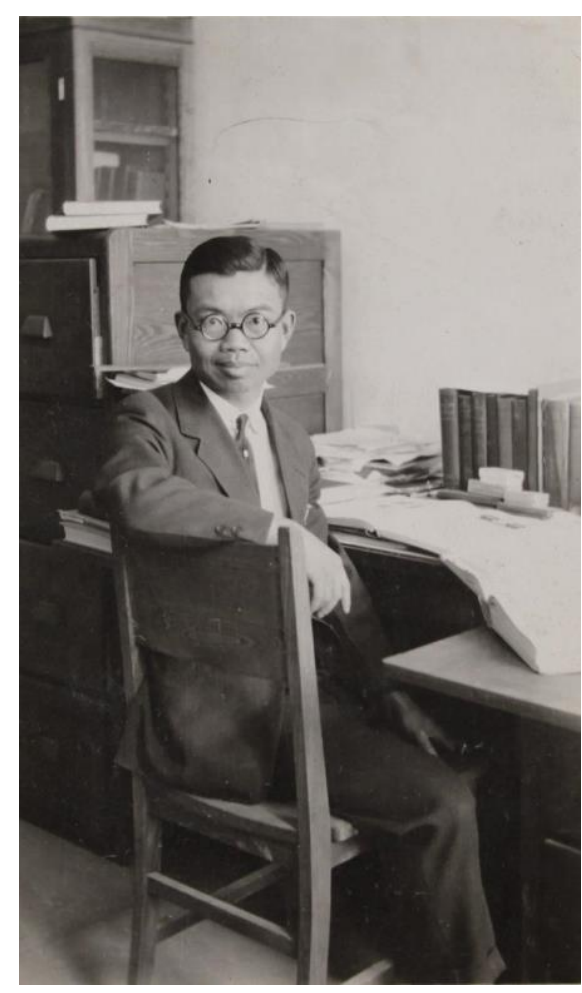

Figure 11: Y. M. Hsieh at his desk in Yenching, Oct. 1927 (Special Collections, Divinity Library, Yale University, The United Board for Christian Higher Education in Asia Records, RG 11, 421-5928, 7251).

\section{Yu-Ming Hsieh: The first Chinese chair in the Department of Physics}

The unexpected early departure of Anderson was a big loss for the department at Yenching, but it also offered an opportunity for Yu-Ming Hsieh (1895*-1986) (Figure 11). He became the first Chinese to take charge of the department, most likely sooner than the university intended. ${ }^{93}$ Born in a poor family and raised by his widowed mother in Fujian, China, Hsieh received his early education in church schools. Upon his graduation from Westminster College 培元中学, a missionary secondary school in Quanzhou, Fujian, he was admitted to the North China Union College on recommendation. After earning his BA at Peking University** in 1917, Hsieh taught physics and mathematics at Westminster College until 1921, when he returned to Beijing at the invitation of Corbett, Hsieh's former professor at NCUC. ${ }^{94}$ During 1921-1923, Hsieh not only served as an Instructor of Physics at Yenching, but also took courses in physics and physical chemistry at the

\footnotetext{
* Hsieh's matriculation record at the University of Chicago shows that he was born in 1895 rather than 1893 as stated in some of his biographies published in China. Presumably, Hsieh entered the matriculation data himself in Chicago. The record in the Rockefeller Archives, however, shows that Hsieh was born in 1894.

93 In his letter of resignation in January 1926, Charles Corbett had urged Yenching's trustees to consider putting Hsieh or D. K. Yang in charge of the department "as soon as possible." (See Charles H. Corbett to Peking University Trustees, January 8, 1926.) However, the university apparently did not feel that either of these two Chinese physicists was ready, and decided to let Anderson head the department, at least for a transitional period.

** This was the new Peking University, a predecessor of Yenching, born in 1916 out the union of the North China Union College (Congregational) and the Methodist Peking University. One should not confuse this Protestant Peking University with the famous National Peking University (1898-present) to be discussed at the end of this paper. Apparently, Hsieh was initially admitted to the NCUC before 1916, and graduated from the Protestant Peking University in 1917. See Edwards 1959, 76-77.

94 It was very likely that Corbett summoned Hsieh, his protégé, to Yenching in 1921 to help maintain teaching in the department while he was studying at the University of Chicago between 1921 and 1922.
} 
Premedical School of the PUMC, an experience that apparently kindled his desire to study physics in America. Corbett, President Stuart, and Howard S. Galt at Yenching strongly supported Hsieh's plan to study in America, and so did Mr. Bird R. Stephenson of the PUMC Premedical School and Mr. Nathaniel Gist Gee-a former science professor of Soochow University and now an adviser to the Chinese Medical Board (CMB) of the Rockefeller Foundation. In February 1923, the CMB granted Hsieh a fellowship to study "pre-medical subjects in America or Europe for one year beginning approximately August 1, 1923."95

Hsieh began his study abroad at Columbia University in New York City, where he took at least nine courses, eight in physics and one in mathematics (see Table 3), between September 1923 and June 1924, earning his AM degree. By February 4, 1924, Hsieh had informed the $\mathrm{CMB}$ that he wished to study in America one more year, requesting a renewal of his fellowship. ${ }^{96}$ Meanwhile, he also solicited support from people at his university and at the CMB in Beijing. In his letter to President Stuart, Hsieh wrote, ${ }^{97}$

You know my fellowship will be definitely last for one year. Recollecting my previous training in Peking and that now in Columbia University, and thinking of what responsibilities I am going to share with you in Peking Univ., I like to have another year's training in this country.

You know one can not get as much as he wants to get in the first year in a new land where he should spend part of his time and energy to accommodate himself to the new environments. In the following year, he will feel, more or less, at home in many things. Consequently the work done in the second year would be more efficient. The academic standard of our University is growing rapidly and unless I have obtained a pretty good training in my profession, the students who would like to take courses with me, would be poorly taught under my instruction both consciously and unconsciously. This is the reason why I want to get another year's training in my profession.

My application for another year's training in U.S.A. is not for the sake of selfishness but for the benefits of the students who would study with me. And from this, the academic place of our University among the Christian and non-Christian institutions in China would be affected so far as the Physics department is concerned.

95 “Hsieh, Yu-Ming," Box 16, Discipline 13: China Medical Board (CMB) Medical Fellowships; Premedical \& Miscellaneous Subjects, Chinese, Subgroup 2, RG 10.2, Fellowships, Fellowship Recorder Cards, FA426, Rockefeller Foundation records, Rockefeller Archive Center, Card \#1a, \#2a. The fellowship includes a stipend of $\$ 90 /$ month (later increased to $\$ 120 /$ month), tuition, and necessary traveling expenses for Hsieh himself between China and America.

96 Ibid., Card \#2a, \#2b. Hsieh's transcript at the University of Chicago.

97 Hsieh to Stuart, Feb. 4, 1924. Hsieh, Y. M., 1924-1943, Yenching Correspondence, Special Collections, Divinity Library, Yale University, the United Board for Christian Higher Education in Asia Archives, College Files, RG 11, 337-5146. Dr. Hu Shenghua 胡升华 first noticed and quoted this letter (a copy from Hsieh's daughter) in his dissertation: Hu 1998, 80. 
Table 3: Courses taken by Y. M. Hsieh in America, 1923-1926

\begin{tabular}{|c|c|c|c|c|}
\hline University & Term/Year & Course category & Course subject & Teacher's name \& Rank \\
\hline \multirow{9}{*}{$\begin{array}{l}\text { Columbia } \\
\text { University }\end{array}$} & \multirow{4}{*}{$\begin{array}{l}\text { Fall Semester } \\
1923\end{array}$} & Math/Undergrad & Differential Equation & not available \\
\hline & & \multirow{3}{*}{ Physics/Graduate } & Heat and Light (auditing) & $\begin{array}{c}\text { W. L. Severinghaus, Asst. } \\
\text { Prof. }\end{array}$ \\
\hline & & & Analytical Mechanics & G. B. Pegram, Prof. \\
\hline & & & Sound - theory of oscillation & B. Davis, Prof. \\
\hline & \multirow{5}{*}{$\begin{array}{c}\text { Spring } \\
\text { Semester } 1924\end{array}$} & \multirow{5}{*}{ Physics/Graduate } & Electricity & H. W. Webb, Asst. Prof. \\
\hline & & & Analytical Mechanics & G. B. Pegram, Prof. \\
\hline & & & $\begin{array}{c}\text { Ionization of Gases and Electrical } \\
\text { Constitution of Matter }\end{array}$ & B. Davis, Prof. \\
\hline & & & Theory of Modern Optical Instruments & J. P. C. Southall, Prof. \\
\hline & & & $\begin{array}{c}\text { Advanced Course in Light and } \\
\text { Electricity }\end{array}$ & H. W. Webb, Asst. Prof. \\
\hline \multirow{31}{*}{$\begin{array}{l}\text { University } \\
\text { of Chicago }\end{array}$} & \multirow{4}{*}{$\begin{array}{c}\text { Summer } \\
\text { Quarter } 1924\end{array}$} & \multirow{3}{*}{ Physics/Senior } & $\begin{array}{l}\text { Advanced Experimental Physics: } \\
\text { Molecular Physics and Heat }\end{array}$ & $\begin{array}{l}\text { Mr. Blackburn (title and } \\
\text { background unknown) }\end{array}$ \\
\hline & & & Advanced Experimental Physics: Light & G. S. Monk, PhD, Research \\
\hline & & & & Instructor in physics \\
\hline & & Physics/Graduate & Electron Theory & $\begin{array}{l}\text { K. T. Compton, Prot. } \\
\text { (visiting) }\end{array}$ \\
\hline & \multirow{4}{*}{$\begin{array}{c}\text { Autumn } \\
\text { Quarter } 1924\end{array}$} & \multirow{2}{*}{ Physics/Graduate } & Theoretical Physics & A. A. Michelson, Prof. \\
\hline & & & X-rays and Electron Theory & A. H. Compton, Prof. \\
\hline & & Math/Senior & Elementary Theory of Equations & L. E. Dickson, Prof. \\
\hline & & Foreign Language & Elementary German (visit) & P. H. Hagboldt, Asst. Prof. \\
\hline & \multirow{4}{*}{$\begin{array}{c}\text { Winter } \\
\text { Quarter } 1925\end{array}$} & Math/Senior & Theory of Definite Integrals & G. A. Bliss, Prof. \\
\hline & & Physics/Senior & Molecular Physics and Heat & H. B. Lemon, Assoc. Prof. \\
\hline & & Physics/Senior & Light: Advanced Optics (visit) & H. G. Gale, Prof. \\
\hline & & Physics/Graduate & Research in Physics & A. H. Compton, Prof. \\
\hline & \multirow{3}{*}{$\begin{array}{c}\text { Spring } \\
\text { Quarter } 1925\end{array}$} & Math/Senior & Elliptic Integrals and Fourier Series & H. E. Slaught, Prof. \\
\hline & & Graduate & Research Course & H. G. Gale, Prof. \\
\hline & & Foreign Language & English and German Exams & (self-study) \\
\hline & \multirow{6}{*}{$\begin{array}{c}\text { Summer } \\
\text { Quarter } 1925\end{array}$} & \multirow{3}{*}{ Math } & Theory of Functions of a Complex & A C I unn Prof \\
\hline & & & Variable (visit) & \\
\hline & & & Relativity and Quantum Phenomena (I) & A. C. Lunn, Prof. \\
\hline & & \multirow{3}{*}{ Physics } & Spectroscopy & H. G. Gale, Prof. \\
\hline & & & Quantum Theory & F. C. Hoyt, NRC Fellow \\
\hline & & & Research Course & H. G. Gale, Prof. \\
\hline & \multirow{4}{*}{$\begin{array}{c}\text { Autumn } \\
\text { Quarter } 1925\end{array}$} & & Units and Dimensions & A. C. Lunn, Prof. \\
\hline & & Math & Theory of Functions of a Complex & A. C. Lunn, Prof. or \\
\hline & & & Variable & Moulton, Prof. \\
\hline & & Physics & Research Course & H. G. Gale, Prof. \\
\hline & \multirow{4}{*}{$\begin{array}{c}\text { Winter } \\
\text { Quarter } 1926\end{array}$} & Math & $\begin{array}{l}\text { Introduction to Mathematical } \\
\text { Chemistry }\end{array}$ & A. C. Lunn, Prof. \\
\hline & & \multirow{3}{*}{ Physics } & Theoretical Physics & A. A. Michelson, Prof. \\
\hline & & & Electricity \& Magnetism & A. H. Compton, Prof. \\
\hline & & & Research Course & H. G. Gale, Prof. \\
\hline & \multirow{2}{*}{$\begin{array}{c}\text { Spring } \\
\text { Quarter } 1926\end{array}$} & \multirow{2}{*}{ Physics } & Thermodynamics & A. J. Dempster, Assoc. Prof. \\
\hline & & & Electrodynamics & A. H. Compton, Prof. \\
\hline
\end{tabular}

Note: The data in Table 3 are collected and synthesized by this author from Hsieh's records deposited at the Rockefeller Archive Center, his transcript at the University of Chicago, and relevant university catalogs. 
Agreeing that Hsieh's "usefulness" at Yenching "would be greatly increased if he could continue his studies for another session," Stuart did write to Greene in New York on March 1, 1924, endorsing Hsieh's application. ${ }^{98}$ In April, the CMB investigated Hsieh's performance at Columbia by interviewing Professors Pegram, Davis, and Webb, with whom Hsieh took courses. All three agreed that Hsieh "worked hard and has done well in all courses" although none of them considered him a man "of unusual ability." 99 The Board did not approve Hsieh's extension request before his departure from New York to Chicago.

Regardless, Hsieh was determined to study as much as he could while in the US. Hence, merely three days after Columbia's Spring Session ended, Hsieh arrived in the University of Chicago on June 14, enrolling in three physics courses for its Summer Quarter that started on the 17th, three weeks earlier than Columbia's Summer Session. After the CMB finally extended his fellowship for another year on July 24, Hsieh was able to take courses in the following Autumn and Winter Quarters with several eminent American physicists and mathematicians, such as Albert A. Michelson (the first American physicist to win the Nobel Prize in 1907), Arthur H. Compton (1927 Nobel laureate for physics), Henry G. Gale, L. E. Dickson, and G. A. Bliss. He apparently enjoyed his study in Chicago very much. Evidence indicates that he had requested no later than January 1925 for CMB's permission to extend his study for a third year, at his own expense if necessary, ${ }^{100}$ arguing that the time given to his study in America was not sufficient to qualify him "to carry the type of work which [the CMB] wish him to do at Yenching;" he promised that "with another year's work he [would] feel thoroughly qualified." Stuart reluctantly approved Hsieh's request, but Roger Greene, the then CMB Director, considered it "a little unfair" on Anderson, who was scheduled to come to Yenching in summer 1925. Since Corbett would leave for America on leave that summer, Anderson would have to take over all the work in the Department of Physics if Hsieh remained in Chicago. ${ }^{101}$ Likely prompted by Hsieh's request, Corbett inquired of Gale about Hsieh's performance. Gale, who was then not only Hsieh's teacher and the Chair of the Department of Physics, but also the Dean of the Ogden Graduate School of Science at the University of Chicago, told Corbett in February 1925,

[I am] just getting acquainted with Mr. H[sieh] [who] impresses me as being rather more alert than [the] usual Chinese student, and I have been quite favorably impressed by his

98 Stuart to Greene, March 1, 1924. Hsieh, Y. M., 1924-1943, Yenching Correspondence, Special Collections, Divinity Library, Yale University, the United Board for Christian Higher Education in Asia Archives, College Files, RG 11, 337-5146.

99 "Hsieh, Yu-Ming," Box 16, RG 10.2, Fellowships, Fellowship Recorder Cards, FA426, Rockefeller Foundation Records, Rockefeller Archive Center, Card \#2b.

100 Ibid., Card \#3b.

101 Ibid., Card \#3a. 
ability. There can be no doubt that he is well above the average of the Chinese students who have come to us and compares favorably with our American students. His grades have been $\mathrm{B}$ in most of his courses, although in the advanced theoretical work his grades have been $C .102$

Comparing Gale's remarks with those of Columbia physicists, one can easily recognize Hsieh's progress after merely two quarters in Chicago. Gale's favorable remarks on Hsieh should have helped the latter's appeal. Despite Greene's opposition, the $\mathrm{CMB}$ eventually came up with a compromise, approving Hsieh's request to continue his work at the University of Chicago for the 1925-1926 academic year, but refusing to offer any additional financial support for the extended stay. ${ }^{103}$ Using his own savings, Hsieh continued his study in America for a third year, earning his doctorate at University of Chicago in the summer of $1926 .{ }^{104}$

Hsieh spent a total of eight quarters at the University of Chicago, during which he took twenty-four courses, audited three more, and completed English and German exams. It is important to note that Hsieh took several courses in mathematics and theoretical physics, including those on relativity and quantum theory, even though his main research interest was in experimental optics. From June 1925 he worked hard in the Ryerson Physical Laboratory for eleven months on his thesis research, which was closely related to Michelson's work concerning the impact of the Earth's rotation on the velocity of light. Within a few weeks after completing his research, he finished writing the dissertation, titled "The Effective Wave-length in White-light Interferometry." Having passed the final examination for his doctorate on June 19, Hsieh sailed from San Francisco on August 3, 1926, bound for China. Exactly one month after Hsieh's departure from America, the University of Chicago officially conferred on him a PhD degree in physics and mathematics. ${ }^{105}$

Furnished with a systematic education in modern physics and requisite research skills gained in the United States, Dr. Hsieh returned to Yenching in fall 1926, just in time for lectures that semester. This newly promoted Assistant Professor (ranking just

102 Ibid., Card \#4a. For information on H. G. Gale, see:

https:// www.lib.uchicago.edu/e/scrc/findingaids/view.php?eadid=ICU.SPCL.GALE\&q=Gale, $\% 20$ Henry\%20Gordon (accessed June 25, 2018)

103 Ibid., Card \#3b.

104 According to Hsieh's transcript at the University of Chicago, he passed the "Final Examination for PhD in Physics and Math" on June 19, but the degree was not conferred until September 3, exactly one month after his departure from America for China. (Hsieh's departure date: ibid., Card \#4a.)

105 Yenching University College of Natural Sciences, Statement Presented to the Rockefeller Foundation, October 1929 (New Haven, CT: Archives of the United Board for Christian Higher Education in Asia, RG 11, 64A-843, Special Collections, Yale Divinity School Library), 50; Yu-Ming Hsieh, Y. M. Hsieh's Matriculation Records at the University of Chicago (Chicago, IL: Office of the University Registrar, University of Chicago). 
below Professor at Yenching) resumed his classroom instructions with two courses, one of which, Advanced Optics, was brand new in Yenching's curriculum, and had an identical title to a course he took in Chicago. Clearly, he was eager to pass on to his students what he had learned in America. His return strengthened the department in not only class instruction, but also scholarly research, making it possible to create the MS program there. As a co-founder of this program, He shared with Anderson the responsibility of directing and supervising the first two graduate students: Wei and Wu. While Anderson mentored Wei, he advised Wu (Figure 12). Supported by Hsieh and other physicists at Yenching as well as at Peking and Tsinghua Universities, Wu completed his MS thesis titled "The Rectification of Alternating Current by Crystals with Metallic Contact" in June 1929, in which he attempted to clarify the mechanism of rectification by crystals, important devices for contemporary wireless telegraphy and telephony. ${ }^{106}$

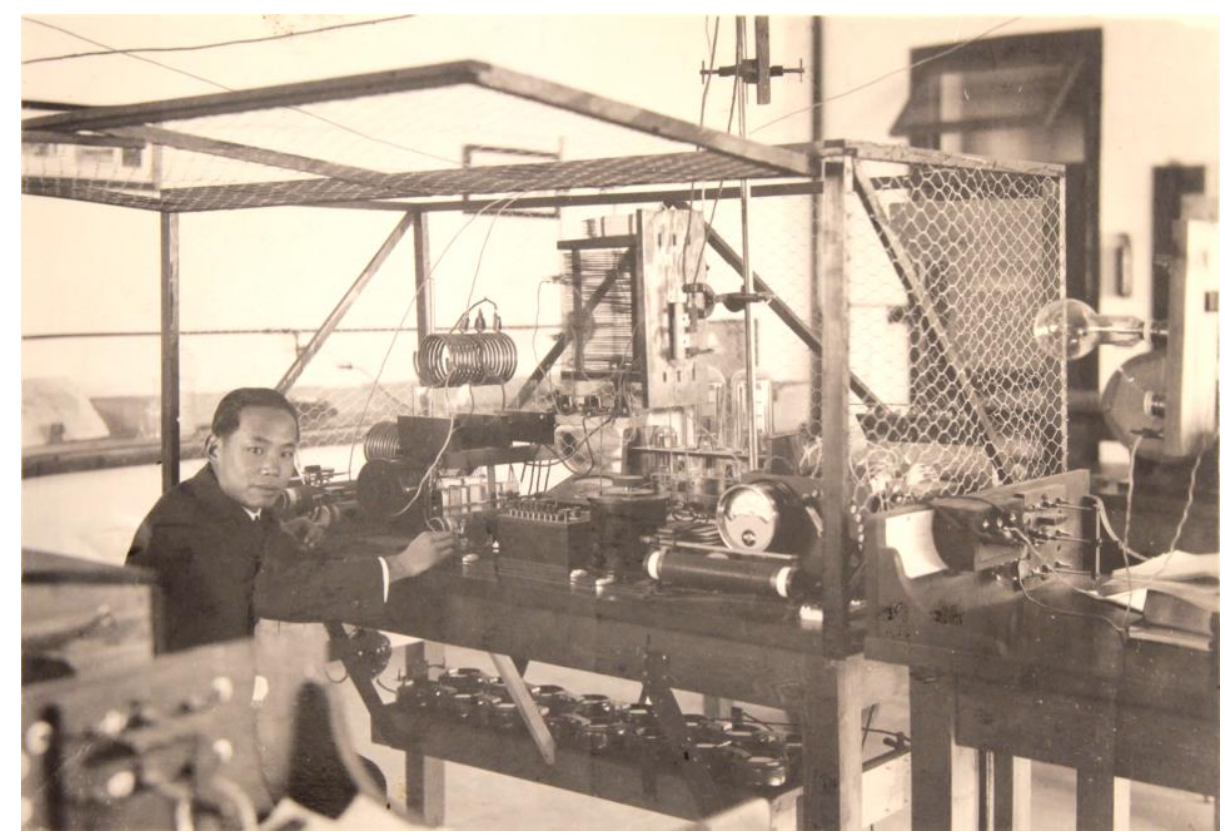

Figure 12: Ching-Huan $\mathrm{Wu}$ and his equipment for the research on "Rectification of Alternating Current by Crystal with Metallic Contact," 1929 (Yenching University, Folder 2708, Box 144, Series 601: China, RF [FA 003], Rockefeller Archive Center).

$106 \mathrm{Wu}$ concluded in his thesis that "the rectifying property of certain crystals may be due to capacity effects and electronic movement, or more briefly, it may be due to a 'Tungar-condenser Effect'." See Wu 1929, 1-2, 49-50. Wu's thesis research was a great example of collaboration between the private Christian Yenching University and two other leading national universities in Beijing. Peking University loaned $\mathrm{Wu}$ "the e/m apparatus" that allowed him to carry out the first part of the experimental work, while Pen-Tung Sah 萨本栋, a physics professor at Tsinghua University, suggested that $\mathrm{Wu}$ conduct this experiment. 
Hsieh, who succeeded Anderson as Department Head in 1928, was likewise a diligent educator. He taught various undergraduate and graduate courses, including general physics, analytical mechanics, physical optics (or advanced optics), molecular physics and heat (or kinetic theory of gases), modern physics, advanced experiments, modern developments in physics, and an outline of theoretical physics. Apparently inspired also by his experience in the University of Chicago, he initiated in Fall 1929 the "Physics Journal Club" at Yenching, which consisted of all instructors as well as graduate students and "senior students" in the Department of Physics. This club met weekly to review and discuss the latest physics literature. Beginning in Fall 1930, the students mentioned above were required to attend the club regularly ( $\mathrm{Chu}$ and $\mathrm{Wu}$ 1987, 185). ${ }^{107}$

Under Hsieh's leadership, the department announced publicly in 1929 that nurturing physics researchers was part of its mission, probably a first in Republican China. According to this first departmental mission statement, 108

The instructional work in physics is directed toward the following ends: (1) the training of premedical and pre-engineering students for professional study; (2) the training of general students in scientific methods of work and in the understanding of the place of physical science in the modern world; (3) the training of teachers of physics; (4) the training of research workers in physics.

Considering the department's historical connections with PUMC and the contemporary demands of the Chinese society, one can understand why "the training of research workers in physics" was of relatively low priority. The new mission, nevertheless, prompted the department to recruit William Band, an energetic young British physicist, as the new instructor for theoretical physics that fall.

107 Also see Yenching University Bulletin, Announcement of Courses, 1927-28, Vol. X (No. 21), Peking, China, September 1927 (Special Collections, Divinity Library, Yale University, the United Board for Christian Higher Education in Asia Records, RG 11, 308-4745), 55；燕京大學本科課程一 覽, 第十一屆, 佈告第二十一號, 民國十七年 [Announcement of Courses For Undergraduate College, Vol. XI, No. 21, 1928], 1928-1929 (Yenching University Archives in Peking University Archives in Beijing, China), 51; Yenching University Bulletin, Announcement of Courses, Graduate Division, 1929-30, Pe[i]ping, China, August 1929 (Yenching University Archives in Peking University Archives in Beijing, China), 31; Yenching University Bulletin, Announcement of Courses, Graduate Division, 1930-31, Vol. XII (No. 20), Peiping, China, August 1930 (Yenching University Archives in Peking University Archives in Beijing, China), 39. When Hsieh was in the University of Chicago, there was a "Physics Club" that was conducted by members of the physics department and met "regularly for the discussion of the results of research work done in the Ryerson Laboratory and elsewhere" (University of Chicago 1922, 255). The prerequisite for Yenching's "Physics Journal Club" was two years of courses in physics; students who met that requirement were so-called "advanced students" or "senior students."

108 Yenching University Bulletin, College of Natural Sciences, Announcement of Courses, 1929-30, Peping, China, July 1929 (Yenching University Archives in Peking University Archives in Beijing, China), 44. 
Hsieh emphasized experimental work, and underscored the cultivation of students' practical ability to operate in the laboratory. In 1931, he offered two more new courses. One was "Advanced Experimental Optics," taught concurrently with his "Advanced Optics." This new experimental course dealt with "lens systems, prisms, diffraction phenomena due to single slit, double slit, diffraction grating of the concave reflection types, photometer, refractometer, Michelson interferometer, polariscope and polarimeter." The other was "The Teaching of Physics," which offered students not only "experience in the preparation of laboratory materials, in the conduct of laboratory work under supervision and in helping professors to set up demonstration lectures for General Physics," but also opportunities for "making and repairing simple physical apparatus" (Chu and Wu 1987, 185). ${ }^{109}$ In 1933-1934, Hsieh was scheduled to teach new courses such as "Atomic Physics," "Electron Physics," and "Spectroscopy," but he did not return to Yenching from California until the following year. 110

Hsieh proved to be an accomplished researcher, and his most important work was completed at the California Institute of Technology (Caltech) between 1932 and 1934. Collaborating with William V. Houston (1900-1968) at Caltech, in 1933 he completed some very significant experiments that "[bore] directly on the worth of quantum field theory in general and the renormalizability of quantum electrodynamics in particular." Examining the fine structure of the Balmer lines of hydrogen, Houston and Hsieh found a "large" - about 3 percent-discrepancy between the theoretical prediction and their experimental results. Based on their "sufficiently accurate" measurements and inspired by J. Robert Oppenheimer's and Niels Bohr's remarks concerning the widespread ignorance of "the effect of the interaction between the radiation field and the atom" or self-energy in contemporary theoretical predictions, they boldly suggested that "the theory is no longer satisfactory," and attributed the discrepancy to "the effect of the interaction between the radiation field and the atom [that is, self-energy]." Houston was the primary investigator in this experiment, and, being well versed in theoretical quantum mechanics, likely led the investigation to reach this remarkable conclusion. Unfortunately, their excellent paper was largely neglected and remained forgotten for more than a decade until Willis Eugene Lamb (1913-2008) confirmed the same discrepancy with his precise measurements in a newly designed experiment in late 1947. In 1955, Lamb received the Nobel Prize in Physics "for his discoveries concerning the fine structure of the hydrogen spectrum." The significant contribution of Houston and Hsieh was nevertheless not recognized until 1986, when Crease and

109 Also see Yenching University Bulletin, College of Natural Sciences, 1931-1932, Vol. XVI (No. 25), Peiping, China, June 1931 (Yenching University Archives in Peking University Archives in Beijing, China), 71, 73.

110 Yenching University Bulletin, Graduate Division, 1933-34, Vol. XVIII (No. 20), Peiping, China, July 1933 (Yenching University Archives in Peking University Archives in Beijing, China), 30-31. 
Mann published their study concerning the intriguing genesis of the famous Lamb Shift. ${ }^{111}$

\section{William Band: A "mathematical and practical" physicist from England}

When Hsieh left Beijing in 1932 for Pasadena to work at Caltech, William Band (1906-1993) took over as Department Chair. Band received his MS from the University of Liverpool (UoL) in 1927, with a master's thesis titled "An Examination of Professor Whitehead's Theory of Relativity," which was praised by Arthur S. Eddington. According to Eddington, the MS thesis "fell only [a] little short of the standard" for an ordinary PhD dissertation in Britain. ${ }^{112}$ In 1929, the Department of Physics at Yenching was very happy to hire this twenty-three-year-old teaching assistant at UoL, not only because of the shortage of staff in the department after Anderson's departure, but also, or even mostly, because of Band's "particular qualifications," which "fit[ted] in very well with their needs." 113 Apparently the department needed someone like Band who was able to teach and lead students' research in both theoretical and experimental physics. His thesis on relativity demonstrated his theoretical qualifications. Moreover, Band also had substantial working experience in experimental physics. After earning his MS, he, while serving as a "Demonstrator" in the Department of Physics at UoL, collaborated with A. J. Maddock, a graduate student, in research on the crystal structure of titanium dioxide $\left(\mathrm{TiO}_{2}\right)$ by means of X-rays under the direction of $\mathrm{R}$. W. Roberts, Lecturer in the department. According to Roberts, Band and Maddock "very

111 Born in Mount Giliad, Ohio, William V. Houston received a BA in physics and a BS in education from Ohio State University (OSU) in 1920. After studying with Michelson, Millikan, and Gale, and earning his MS degree at the University of Chicago in 1922, Houston returned to OSU and received his PhD in physics in 1925. He was a 1925-27 National Research Fellow, working at Caltech on "experimental and theoretical study of spectral fine structure." As a Guggenheim Fellow, Houston also studied in Germany in 1927-28, working with Sommerfeld and then Heisenberg. From 1928, he was on the faculty of Caltech until becoming the second president of the Rice Institute in 1946. See National Research Council (US) 1944, 30. Interview of William V. Houston by Gerald Phillips and W. J. King on March 3, 1964, Niels Bohr Library \& Archives, American Institute of Physics, College Park, MD US, www.aip.org/historyprograms/niels-bohr-library/oral-histories/4682; "Biographical Note" in Texas Archival Resources Online n.d.; Crease and Mann 1986, 110-128, the quotes appear on pages 110, 113; "Willis E. Lamb: Facts," in Nobelprize.org n.d. Houston as the primary investigator: On February 16, 1933, Hsieh wrote to the Rockefeller Foundation, saying that he was doing research under Houston's guidance ("Hsieh, Yu-Ming," Box 16, RG 10.2, Fellowships, Fellowship Recorder Cards, FA426, Rockefeller Foundation records, Rockefeller Archive Center, Card \#4b).

112 James Rice, Recommendation Letter, August 14, 1934. Special Collections, Divinity Library, Yale University, the United Board for Christian Higher Education in Asia Records, RG 11, 320-4877.

113 J. B. Tayler to W. Band, March 14, 1929. 
ably carried out" their research, which "proved invaluable to the development of this subject by subsequent workers in this department." James Rice, Band's MS thesis advisor, therefore, stated that when Band left Liverpool for Beijing in 1929, "he was exceptionally well equipped for his age on the mathematical and practical sides of physical science."114

Band arrived in Yenching at the end of September (Figure 13). His arrival greatly helped the Department of Physics both in coping with the growing student enrollment, and in enhancing its graduate education and research. It is said that the department admitted twenty freshmen in 1931, and it maintained a similar annual admission rate in the following few years (Pan, $\mathrm{Wu}$, and Fan 1993, 494-495). 115 The increasing number of Yenching's physics graduates in the 1930s, as shown in Table 4, indeed indicates the growing undergraduate as well as graduate student enrollment since 1927; enrollment, however, fluctuated over the following decade.

At Yenching, Band was a diligent and popular mentor with broad teaching and

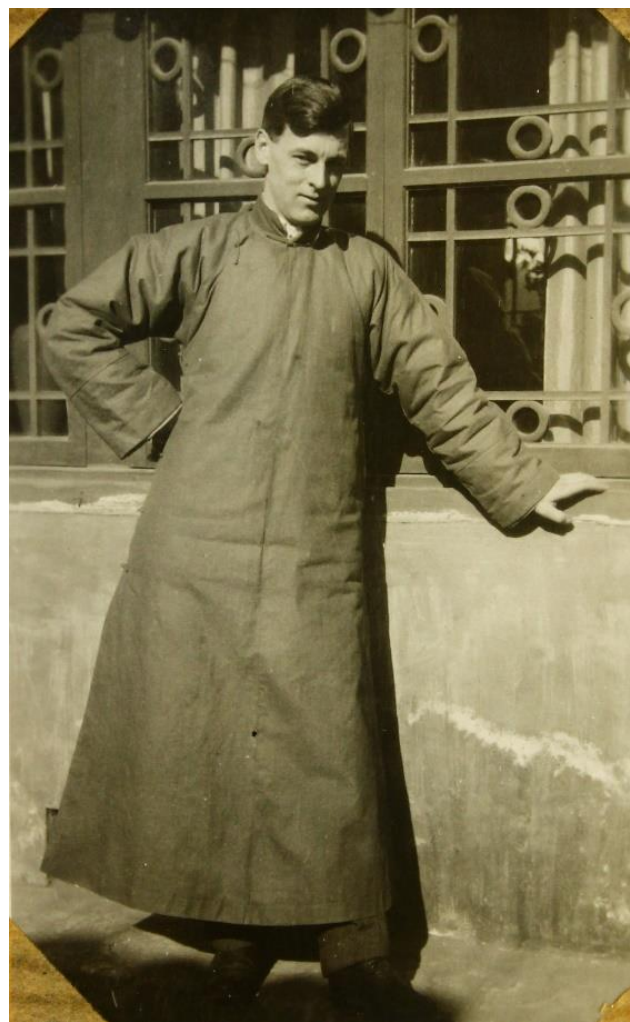

Figure 13: William Band in traditional Chinese dress standing in apparently his residence at Yenching likely soon after his arrival in China (Cage 617, William Band Papers. Manuscripts, Archives, and Special Collections, Washington State University Libraries, Pullman, WA). research interests. During his eleven-year-residence in Beijing, he taught at least twenty-four different courses, which covered a wide-range of subjects from elementary "college physics" to advanced "relativity theory" and "quantum mechanics," from experimental "premedical laboratory" to mathematical and theoretical "tensor and vector analysis" and "statistical mechanics," and from practical and specialized

114 R. W. Roberts, Letter, July 10, 1934; William Band, Autobiography: William Band (Cage 617, Box 2, Folder 12-14; William Band Papers. Manuscripts, Archives, and Special Collections, Washington State University Libraries, Pullman, WA, US), 1981, V-6; James Rice, Letter, August 14,1934 .

115 The claimed admission of twenty freshmen in 1931 appears to contradict the fact that the department awarded no BS degree in 1935 (see Table 3) when that group of students were scheduled to graduate. It is hard to believe that all these twenty students would have failed to graduate. 
"meteorological physics" and "thermo-magnetic effect" to metaphysical "natural philosophy of modern physics."

It was particularly remarkable for Band, a twenty-four-year-old instructor of theoretical physics, to commence "The Natural Philosophy of Modern Physics" at Yenching, which must have been the first college course of its kind in China. This seminar began with a summary of the theories of relativity, wave mechanics of the atom, and statistical mechanics, and then explored the natural philosophy of Alfred $\mathrm{N}$. Whitehead, Charlie D. Broad, Bertrand Russell, and Arthur Eddington. Band intended to give students in various disciplines "a grasp of the significance of [modern physics]." By design, this course was not "exactly elementary in nature." Although Band attempted to keep its physics content "as non-technical as possible," there remained "sufficient difficulty" "in understanding the philosophical part of the subject." Band therefore restricted the participants of his seminar to "mature" or graduate students, who he had personally approved. ${ }^{116}$ The seminar was apparently so successful that Band offered it in three consecutive years and a total of four times before 1935. In fact, it attracted not only advanced students, but also some professors from other departments. For instance, Dr. Randolph C. Sailer of the Department of Psychology and Dr. Lechung Tsetung Hwang 黄子通 (Huang Zitong) of the Department of Philosophy attended the seminar; both of them, according to Band, offered "many helpful suggestions" and had "thought-provoking discussions" with the young instructor. ${ }^{117}$ Probably partially inspired by the seminar and his discussions with Band, Hwang, then a full professor and Department Chair, later published an essay about Whitehead's theory of space-time (Hwang 1935). ${ }^{118}$

Table 4: Yenching graduates in physics (BS \& MS), 1929-1941119

\begin{tabular}{|c|c|c|c|c|c|c|c|c|c|c|c|c|c|c|}
\hline & 1929 & 1930 & 1931 & 1932 & 1933 & 1934 & 1935 & 1936 & 1937 & 1938 & 1939 & 1940 & 1941 & Total \\
\hline BS & 2 & 1 & 6 & 5 & 3 & 4 & 0 & 6 & 9 & 6 & 8 & 4 & 11 & 65 \\
\hline MS & 2 & 0 & 2 & 2 & 2 & 8 & 2 & 3 & 1 & 2 & 0 & 6 & 2 & 32 \\
\hline
\end{tabular}

116 Yenching University Bulletin, Announcement of Courses, Graduate Division, 1930-31, Vol. XII (No. 20), Peiping, China, August 1930 (Yenching University Archives in Peking University Archives in Beijing, China), 39.

117 William Band, The Philosophy of Modern Physics (unpublished manuscript: Washington State University Libraries, Manuscripts, Archives, and Special Collections, Pullman, WA, US, 1931), "Foreword." Band spelled Hwang's name as "L. T. Huang."

118 Also see Yenching University Directory 燕京大學教職員學生名錄, 1930-1931, Vol. XII (No. 14), Peiping, China, October 1930 (Special Collections, Divinity Library, Yale University, the United Board for Christian Higher Education in Asia Records, RG 11, 308-4750, "Yenching Academic Directories, 1930-1932"), 5. Hwang was an uncle of Huang Kun 黄昆 (1919-2005), a famous Chinese physicist, who earned his BS at Yenching in 1941 under Band's direction.

119 This table is a result of this author's examination of existing theses of Yenching's physics department deposited in Peking University Library in Beijing, China as well as School of Natural Sciences at Yenching University 燕大理學院; “Alumni Address” 1940, 22-24. 
Between 1930 and 1941, Band also supervised 26 BS and 22 MS theses, which represented respectively $42 \%$ and $73 \%$ of the total number of relevant degrees the department awarded during that same period. Most of these theses dealt with experimental subjects. Of the total of forty-eight theses, only $7(14.6 \%)$ were theoretical treatises. This ratio was highly unusual when considered in the light of the development of modern theoretical physics in China at that time.

As a theoretical physicist working in Beijing, Band soon became keenly aware of peculiar local challenges. In his 1933 essay "Modern Theoretical Physics in China," he discussed the value of theoretical physics in the country, the status of the subject in Chinese universities, and ways for improving its instruction in colleges. Band recognized that theoretical physics was then "one of the most vulnerable to the common criticisms of university enterprises in China" because it "appear[ed] to be the least connected with the needs of the nation; and advanced work in the subject the least useful of all research." He admitted that as a subject of research, theoretical physics was actually "a hobby" instead of "a vocation" in China, and hence had "a subordinate place in the [university] curriculum." Nevertheless, he valued the subject as an efficient "mental gymnastics" and for "its inherent stimulating interest." More importantly, he argued that advanced work in theoretical physics could keep China "[in] touch with the progress in other countries" and help "maintain her position in the world of Science." After all, Band believed, "China cannot afford to be always training her progressive physicists abroad!" In conclusion, he observed,

[T] heoretical physics has not yet come to its own in this country. Probably the natural emphasis on technical science will delay the otherwise inevitable process of growth for some time, but already sufficient original work has been done by Chinese physicists to prove that eventually their breed will be as prolific in theoretical research as the [W] estern variety. (Band 1933, 105-110)

By 1934, Band's experience had taught him that many Chinese students had "a considerable natural aptitude for theoretical work," but that there was practically no place in China where they could receive adequate training in theoretical physics. He therefore planned to spend his prospective 1935-1936 sabbatical leave engaging in advanced theoretical studies at Harvard University "in order to bring back to Yenching a better stimulus for more complete and proportionate development therein." Being chiefly interested "in the philosophical basis of modern theoretical physics," he wished to set up a "joint major" where students would study and benefit from both physics and philosophy. ${ }^{120}$

120 William Band, "To The Rockefeller Foundation: Application for Fellowship for Advanced Study in Physics at Harvard University, Cambridge, Massachusetts," ca. December 1934. Special Collections, Divinity Library, Yale University, the United Board for Christian Higher Education in Asia Records, RG 11, 320-4877. 
To achieve this objective, in December 1934 he applied for a fellowship from the Rockefeller Foundation but failed to get one. Apparently, it was an inopportune application as, from around late 1933, the foundation's fellowship program in China had been undergoing significant changes, greatly reducing the number of "foreign fellowships" that were used to support college natural science teachers from China to study abroad. From then on, the foundation's emphasis for the small number of "foreign fellowships" it continued to offer was on supporting those in practical fields or applied sciences concerning China's rural reform programs rather than the pure sciences. ${ }^{121}$ Under such a situation, there was little chance for Band's research proposal in theoretical physics to be funded. He thus had to postpone his sabbatical, going instead to Cambridge University in 1936-1937, where he studied with Ralph Fowler, Arthur Eddington, Paul Dirac, and Rudolf Peierls. Fowler had the most influence on his later teaching and study, and he later not only added a new course, "Statistical Mechanics," to Yenching's curriculum, but also supervised four theoretical theses in statistical physics, all completed between 1940 and 1941. His popular textbook $A n$ Introduction to Quantum Statistics was also first drafted at Yenching after his return from Cambridge (Band 1955). ${ }^{122}$

Fully recharged from his time in Cambridge, Band returned to Beijing in the summer of 1937. He would quickly realize, however, that he could no longer fulfill his wish to establish a study center for theoretical physics, because the Japanese army had occupied the city, and launched the full-scale invasion of China just prior to his arrival. By the time he re-entered the Yenching campus in late August, many of its faculty and students had departed Beijing, including both Hsieh and Meng, leaving the department with no faculty ranking at either Full Professor or Lecturer. As the head and sole remaining Assistant Professor in the department during 1937-1938, and the only Full Professor thereafter, he was forced to spend most of his time and energy maintaining the department's normal operations; there was little chance for him to prepare and launch a new program for theoretical physics before he had to flee from Beijing himself at the end of 1941.

Despite the shortage of senior faculty and other hardship in the aftermath of the

121 For the circumstances surrounding such a policy change, see The Rockefeller Foundation n. d. and Gunn to Mason, Dec. 4, 1933, Folder 348, Box 42, Series 601E, RG 1.1, Projects, FA386, Rockefeller Foundation records, Rockefeller Archive Center. See also Gunn to Hanson, March 19, 1935, Folder 349, Box 42, Series 601E, RG 1.1, Projects, FA386, Rockefeller Foundation records, Rockefeller Archive Center; Gunn to Mason, August 26, 1935, Folder 349, Box 42, Series 601E, RG 1.1, Projects, FA386, Rockefeller Foundation records, Rockefeller Archive Center.

122 Also see Willam Band, "William Band: Interview by George E. Duvall and James L. Park, April 25, 1985," transcript, Archives 202 Box 1, WSU Centennial Oral History Project, Manuscripts, Archives, and Special Collections, Washington State University Libraries, Pullman, WA., 11-12. 
Japanese occupation of Beijing, Band managed to keep the department running with normal or even better productivity in the following four years, as shown in Table 2. By 1940, compared with its counterparts elsewhere in the country, the Yenching Department of Physics apparently excelled at nurturing researchers who were able to carry out original studies. When the Chinese Physical Society convened its eighth annual meeting in Kunming in September 1940, a total of forty papers were presented, of which Yenching's faculty and students submitted twelve (30\%), with Band co-authoring five ("The Eighth Annual Meeting" 1940, 21; Zhongguo Wuli Xuehui liushi nian 1992, 7).

\section{Concluding remarks: Yenching as a prominent cradle of Chinese physics research}

Within the timespan of about two decades, the Department of Physics at Yenching University grew from a premedical training center to a prominent cradle of Chinese physics research. This success was due, above all, to the enlightened leadership and commitment of the first four Department Chairs. Corbett, an American missionary with a great deal of passion for, but limited scientific training in, physics, founded the department. He clearly realized the importance of advancing professional work there, even though he had no desire to become a professional physicist himself. Hence, he recruited Anderson, a promising young researcher from Harvard, and actively supported Hsieh's graduate study in the United States. Anderson initiated and stressed original research among the students and faculty, requiring students to produce a bachelor's thesis and launching the first MS program in physics in China. Hsieh actively promoted original experimental research that often addressed practical issues of significance in Chinese society. Under his leadership, "the training of research workers in physics" became part of the department's mission in 1929. He also strengthened theoretical study there by recruiting William Band. Band chaired the department between 1932 and 1941, and supervised most of the MS theses completed there. In fact, he probably directed more MS students in physics than anyone else in Republican China. He provided one of the most comprehensive sets of courses in advanced theoretical physics at Yenching, and supervised the first master's thesis in modern theoretical physics in the country (Band 1933, 106). ${ }^{123}$ It is also important to note that Anderson, Hsieh, and Band were all active and accomplished researchers

123 Since Band stated that he did not find in 1933 "any master theses written on theoretical topics," H. Y. Hsu's 1934 thesis "Relativity and Wave Mechanics" became probably the first MS thesis in China concerning modern theoretical physics. (C. C. Wang or J. S. Wang 王竹溪 at Tsinghua University published a theoretical paper titled "Turbulent Wake behind a Body of Revolution" also in 1934, but it is not on modern physics.) 
themselves.

Abundant private funding, largely from America, and deep educational connections with Western institutions were also essential elements in the department's success. The Rockefeller Foundation played a unique role in advancing physics education and research at Yenching, either directly or via the China Medical Board and the PUMC. As demonstrated in the discussions above, the foundation was the department's leading benefactor right from the beginning, when Yenching's students were invited to share the lectures and laboratory facilities in the PUMC Premedical School. The foundation also handed over the entire School, together with its library and laboratory equipment, to Yenching in 1925, and funded advanced training overseas for department faculty, such as Corbett, Hsieh, Yang, and Meng. It not only covered Anderson's and Band's salary, but also supported their research projects in Beijing. Sponsored by the foundation, Yenching faculty and students were able to study at prestigious American institutions, such as Columbia, the University of Chicago, the University of Michigan, Caltech, and Harvard. The foundation, however, never seemed to have deliberately supported any project in the basic sciences in China, which frustrated Band's attempts to develop theoretical physics in the country. Nevertheless, Yenching physicists could always find innovative ways to benefit from the foundation's ventures in China, whether in medical education or the Rural Reconstruction Movement (RRM). The department's connections with its counterparts in Britain also helped create opportunities for its students to receive advanced training there. W. Y. Chang and Y. K. Hsü, two of Band's graduate students, for example, did research with Ernest Rutherford at the University of Cambridge and James Chadwick at the University of Liverpool, respectively.

One of the striking features of physics at Yenching was its intensive attention to local and practical issues (Figure 14). Of forty-three BS and MS theses ${ }^{124}$ completed between 1930 and 1936, twenty (47\%) dealt with local or practical problems (see Table 5). Several factors must have contributed to this. First, with its motto "Freedom through Truth for Service," Yenching actively encouraged its faculty and students to use their knowledge to serve conscientiously local society. Second, Y. M. Hsieh was a believer in John Dewey's pragmatist philosophy in scientific education. Third, and perhaps most influentially, the early 1930s coincided with the RRM, which aimed at reconstructing through education the culture, economy, health, and political awareness of rural area. Both Hsieh and Band clearly shared the ideals of the RRM, and were enthusiastic in leading their students to participate in it. The treatise on Chinese window paper mentioned at the beginning of this essay was just one example of such efforts. Fourth,

124 These forty-three theses are those I have been able to find in the Yenching University Archives at Peking University Library. Although it may not be exhaustive, not many are likely missing from this list. 
since the Rockefeller Foundation - a main funding source for Yenching - had decided to concentrate on supporting works in "practical fields", such as the RRM, rather than elite medical education, it was necessary for Yenching to take corresponding measures to accommodate its sponsor.

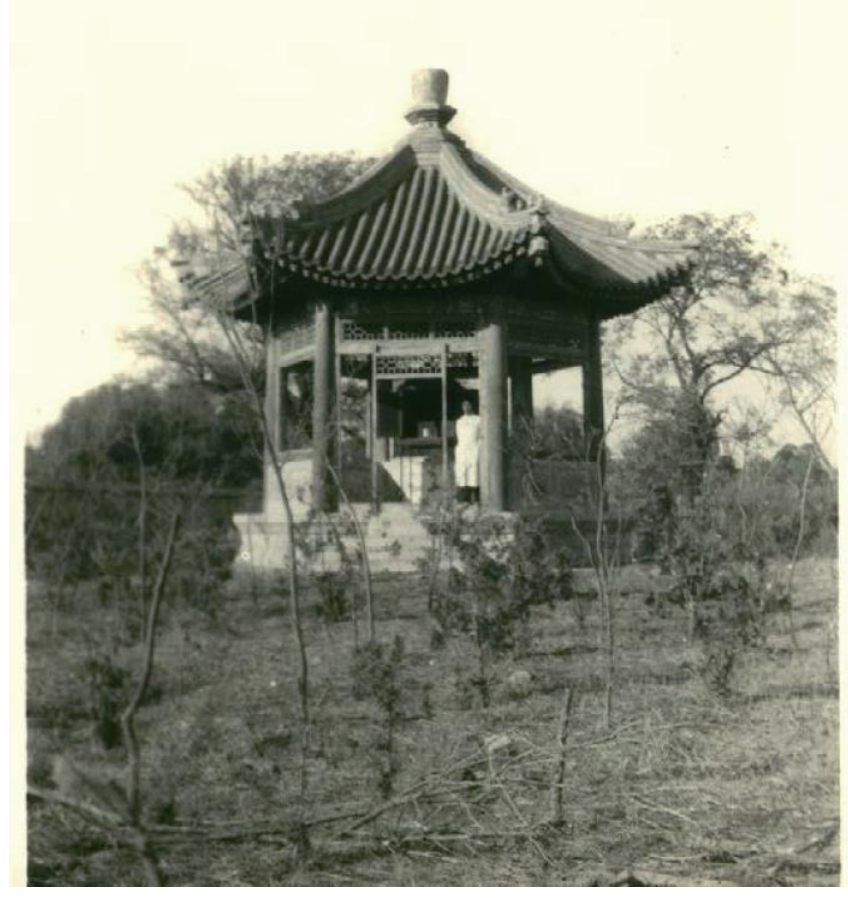

Figure 14: Pavilion with weather-recording instruments on Yenching Campus (Special Collections, Divinity Library, Yale University, the United Board for Christian Higher Education in Asia Records, RG 11, 419-5890, 7037).

Another outstanding trait of the department was that it nurtured more female physics researchers than any of its contemporaries in China (Figures 15 and 16). Yenching awarded a BS to its first female graduate in physics, Ming-Chen Wang (王明 贞, 1906-2010, hereafter M. C. Wang), as early as 1930. By Fall 1937, at least seven female students had earned their BS degree at Yenching, and two of them, M. C. Wang and Cheng-Shu Wang (王承书, 1912-1994, hereafter C. S. Wang) earned their MS in 1932 and 1936 respectively. ${ }^{125}$ In contrast, Tsinghua University, the most prestigious national university in the country, produced no female BS in physics until 1936. A mere

125 C. S. Wang was known in the West as C. S. Wang Chang because she married W. Y. Chang, another prominent graduate from Yenching, who earned his BS (1931) and MS (1932) under Band's supervision. 
Table 5: Yenching's physics theses on local and practical problems, 1930-1936126

\begin{tabular}{|c|c|c|c|c|}
\hline Author & Degree & $\begin{array}{c}\text { Date of } \\
\text { Completion }\end{array}$ & Supervisor & Thesis Title \\
\hline $\begin{array}{l}\text { Ming-Chen Wang } \\
\text { 王明贞 }\end{array}$ & BS & 1930.6 & Y. M. Hsieh & $\begin{array}{l}\text { A Study on the Variation of [the] Reflective } \\
\text { Index of Cow's Milk }\end{array}$ \\
\hline $\begin{array}{l}\text { Wen-Yü Chang } \\
\text { 张文裕 }\end{array}$ & BS & 1931.5 & W. Band & $\begin{array}{l}\text { Air-Earth Electrical Current Measurement of } \\
\text { Atmospheric Conductivity in Yenching }\end{array}$ \\
\hline $\begin{array}{l}\text { Fang-Hsien Tsai } \\
\text { 蔡方宪 }\end{array}$ & BS & 1931.5 & $\begin{array}{l}\text { Y. M. Hsieh; } \\
\text { Y. K. Hsü }\end{array}$ & $\begin{array}{l}\text { The Determination of the Latitude and } \\
\text { Gravity at Yenching University with } \\
\text { Foucault's Pendulum }\end{array}$ \\
\hline $\begin{array}{c}\text { Chen-Yü Ma } \\
\text { 马振玉 }\end{array}$ & BS & 1931.6 & Y. M. Hsieh & $\begin{array}{l}\text { A Photometrical Study of Some Ordinary } \\
\text { Electric Lamps by Means of the Lummer } \\
\text { Brodhun Photometer }\end{array}$ \\
\hline $\begin{array}{l}\text { Yung-Chen Chao } \\
\text { 赵永珍 }\end{array}$ & BS & 1932.5 & $\begin{array}{l}\text { D. K. Yang; Y. M. } \\
\text { Hsieh }\end{array}$ & $\begin{array}{c}\text { Determination of the Horizontal Intensity of } \\
\text { the Earth's Magnetic Field at Yenching } \\
\text { University }\end{array}$ \\
\hline $\begin{array}{l}\text { Yün-Kuei Hsü } \\
\text { 徐允贵 }\end{array}$ & BS & 1932.5 & Y. M. Hsieh & $\begin{array}{c}\text { Emanation Content of Water Sources in the } \\
\text { Peiping Area }\end{array}$ \\
\hline Ming-Chen Wang & MS & 1932.5 & $\begin{array}{l}\text { W. Band; Y. M. } \\
\text { Hsieh }\end{array}$ & $\begin{array}{c}\text { Photoelectric Measurements of Solar } \\
\text { Radiation at Peiping }\end{array}$ \\
\hline $\begin{array}{l}\text { Wen-chiang Li } \\
\text { 李文江 }\end{array}$ & BS & 1933.1 & C. Y. Meng & $\begin{array}{l}\text { The Electrodynamic Loudspeaker and Its } \\
\text { Construction }\end{array}$ \\
\hline $\begin{array}{l}\text { Jen-Lieh Chen } \\
\text { 陈仁烈 }\end{array}$ & BS & 1933.4 & W. Band & $\begin{array}{l}\text { A Study of Atmospheric Potential Gradient at } \\
\text { Peiping }\end{array}$ \\
\hline $\begin{array}{l}\text { Shang-Yi Chen } \\
\text { 陈尚义 }\end{array}$ & MS & 1934.5 & $\begin{array}{l}\text { C. Y. Meng; W. } \\
\text { Band }\end{array}$ & $\begin{array}{c}\text { The Transmission of Ultraviolet Radiation } \\
\text { through Window Papers }\end{array}$ \\
\hline $\begin{array}{l}\text { Cheng-Shu Wang } \\
\text { 王承书 }\end{array}$ & BS & 1934.5 & W. Band & $\begin{array}{l}\text { Continuous Records of the Atmospheric } \\
\text { Potential Gradient at Yenching }\end{array}$ \\
\hline $\begin{array}{l}\text { Kuo-Chang Wu } \\
\text { 吴国璋 }\end{array}$ & MS & 1934.5 & W. Band & $\begin{array}{l}\text { Thermal Conductivity of China Soils } \\
\text { Collected by the Geological Survey }\end{array}$ \\
\hline $\begin{array}{l}\text { Chia-Liu Yuan } \\
\text { 袁家骝 }\end{array}$ & MS & 1934.5 & W. Band & $\begin{array}{c}\text { Thermal Insulation Efficiency of Textiles } \\
\text { Manufactured in Ching Ho }\end{array}$ \\
\hline $\begin{array}{l}\text { Jun-Chuan Wang } \\
\text { 王润全 }\end{array}$ & BS & 1934.6 & W. Band & $\begin{array}{l}\text { A Portable Radio Transceiver for the } \\
\text { Measurement of Field Intensity }\end{array}$ \\
\hline $\begin{array}{l}\text { Hsing-Hua Chang } \\
\text { 张兴华 }\end{array}$ & BS & 1936.1 & W. Band & $\begin{array}{l}\text { Influence of Temperature on Some Properties } \\
\text { of Chinese Oils }\end{array}$ \\
\hline $\begin{array}{l}\text { Li-Ch'ang Cheng } \\
\text { 程利昌 }\end{array}$ & BS & 1936.1 & Y. M. Hsieh & A Study on an Improved Vegetable Oil Lamp \\
\hline $\begin{array}{l}\mathrm{Hu}-\mathrm{H} \text { siang } \mathrm{Li} \\
\text { 李獲祥 }\end{array}$ & BS & 1936.3 & W. Band & $\begin{array}{l}\text { Apparatus for the Recording of the Variations } \\
\text { of Intensity of Radio Waves Reflected from } \\
\text { the Ionosphere in Different Types of Weather }\end{array}$ \\
\hline $\begin{array}{l}\text { Tsung-Yueh Hsü } \\
\text { 许宗岳 }\end{array}$ & MS & 1936.5 & Y. M. Hsieh & Absorption Spectra of Tung Oil \\
\hline Cheng-Shu Wang & MS & 1936.5 & Y. M. Hsieh & $\begin{array}{c}\text { A Study of Peiping Dust by a Continuous } \\
\text { Recording Device }\end{array}$ \\
\hline $\begin{array}{l}\text { Wen-Chuan Mo } \\
\text { 莫文泉 }\end{array}$ & BS & 1936.6 & Y. M. Hsieh & $\begin{array}{c}\text { The Electrical Conductivity of Some } \\
\text { Insulating Oils }\end{array}$ \\
\hline
\end{tabular}

126 The data in this table are synthesized from my study of Yenching student theses deposited in Peking University Library. 
four women graduated from Tsinghua's Department of Physics before fall 1937, three in 1936 and one in 1937; no woman was ever admitted to its graduate program before 1937.127 At least three of the female graduates from Yenching went on to earn their doctorate at the University of Michigan, among whom were M. C. Wang and C. S. Wang, who studied and later collaborated with George Uhlenbeck, making significant contributions to statistical physics ( $\mathrm{Hu}$ 2016, 284-287; Wang and Uhlenbeck 1945; Chang and Uhlenbeck 1951; Chang and Uhlenbeck 1970).

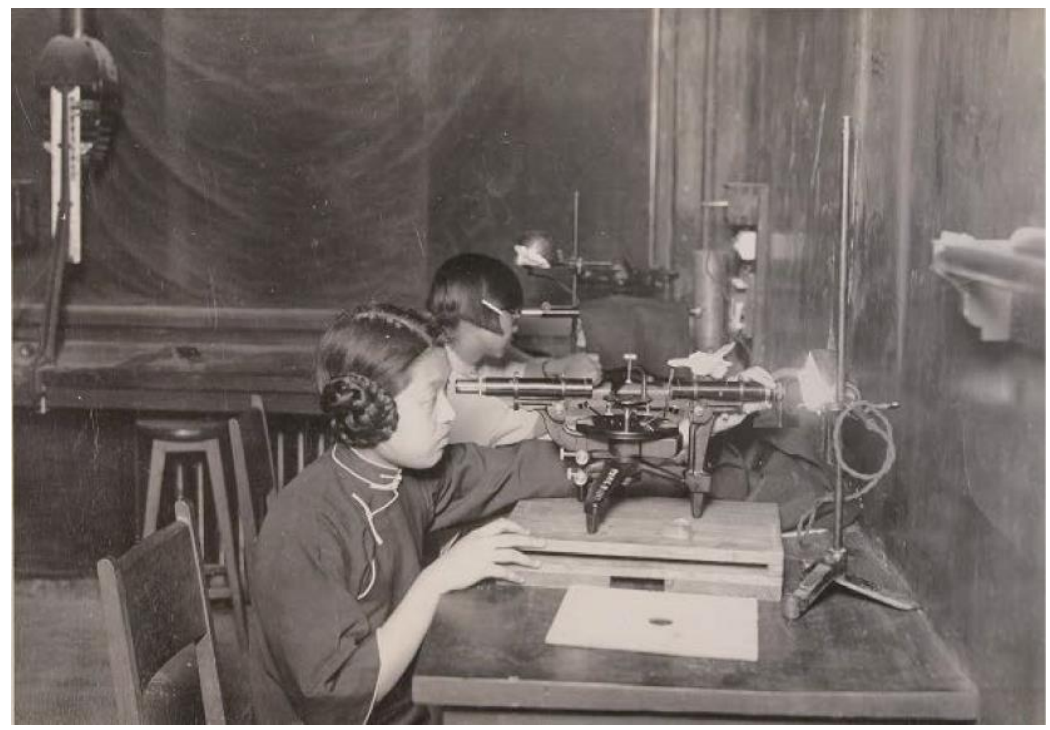

Figure 15: Female students in a physics laboratory at Yenching University (Special Collections, Divinity Library, Yale University, the United Board for Christian Higher Education in Asia Records, RG 11, 419-5889, 6031)

Indeed, what the department accomplished was even more striking if we compare it with its counterparts in China. By 1937, more than thirty college physics departments had been established in China (Luo 2001, 138), of which only Yenching, Tsinghua, and Peking Universities set up their MS program in physics before 1936 (Sun 2006, 476, footnote (1)). It is therefore enlightening to compare these three.

Peking, Tsinghua, and Yenching Universities were all in the city of Beijing; while Peking University was situated in the city center, the other two were located in a northwest suburb neighboring each other. In the 1930s, the physics departments in these three schools all imitated their counterparts in America. After all, most of their

127 For a complete list of college graduates (BS) in physics from Tsinghua University, see The Research Department for the History of Tsinghua 1991, 784, 792, 799, 808, 819-820, 825-826, 833, 843-844, 856-857. According to Hu Shenghua, only nine men earned their master's degree in physics at Tsinghua before 1947 (adding J. S. Wang who he apparently missed). See Hu 1998, 63. 


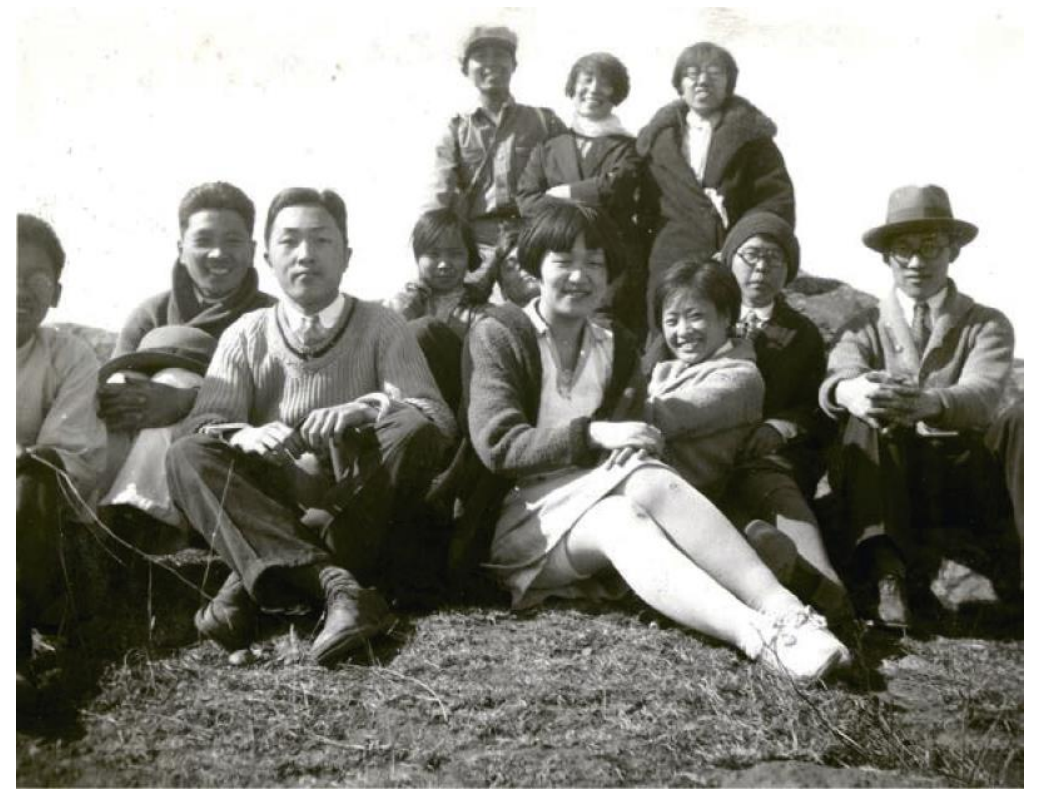

Figure 16: Five female students appeared in this picture taken during a Yenching Department of Physics outing in the suburb of Beijing. Among the people in this picture are Miss M. C. Wang (王明贞, fourth from the right and sitting), W. Y. Chang (张文裕, first from the left and standing), and William Band (fifth from the right and sitting, just half of his face visible behind Wang) (Cage 617, William Band Papers. Manuscripts, Archives, and Special Collections, Washington State University Libraries, Pullman, WA).

Table 6: The Departments of Physics at Peking, Tsinghua, and Yenching before 1937128

\begin{tabular}{|c|c|c|c|c|c|c|c|c|}
\hline \multirow{2}{*}{$\begin{array}{c}\text { Name of } \\
\text { university }\end{array}$} & \multirow{2}{*}{$\begin{array}{l}\text { Start of the } \\
\text { university }\end{array}$} & \multirow{2}{*}{$\begin{array}{l}\text { Start of the } \\
\text { department }\end{array}$} & \multirow{2}{*}{$\begin{array}{l}\text { First BS } \\
\text { graduate }\end{array}$} & \multirow{2}{*}{$\begin{array}{c}\text { Start of } \\
\text { MS } \\
\text { program }\end{array}$} & \multirow{2}{*}{$\begin{array}{l}\text { First MS } \\
\text { graduate }\end{array}$} & \multicolumn{2}{|c|}{ Total } & \multirow{2}{*}{$\begin{array}{c}\text { Senior } \\
\text { faculty in } \\
\text { the } 1930 \mathrm{~s}\end{array}$} \\
\hline & & & & & & BS & MS & \\
\hline Peking & 1898 & 1913 & 1916 & 1935 & $\mathrm{n} / \mathrm{a}$ & 221 & 0 & 7 \\
\hline Tsinghua & 1925 & 1926 & 1929 & 1929 & 1933 & 53 & 2 & 7 \\
\hline Yenching & 1918 & ca. 1918 & 1922 & 1927 & 1929 & 43 & 22 & 3 \\
\hline
\end{tabular}

leading faculty were trained in the United States, and their daily work was mainly funded by either the refunded part of the American share of the Boxer Indemnity or private American sponsors such as the Rockefeller Foundation. Depending essentially on appropriated funds from China's central government, Peking University's finances

128 The data on Peking and Tsinghua universities were drawn respectively from Shen and Zhao 2013, 17-30; Hu 1998, 60-78; The Research Department for the History of Tsinghua 1991, 561, 646-647, 784, 792, 799, 808, 819-820, 825-826, 833, 843-844, 856-857. Lu Xueshan 陆学善 and probably Jwu-Shi Wang were the only two MS degree recipients at Tsinghua before the summer of 1937. 
remained precarious until the early 1930s, when it received large grants from the China Foundation that was established with remitted Boxer Indemnity monies; from the beginning, Tsinghua carried out its work with stable financial support from the refunded Boxer Indemnity fund; and Yenching's successful operation relied almost entirely on, usually ample, private funds raised both overseas and in China. ${ }^{129}$ As shown in Table 6, Peking University, the oldest national university in the country, was the first to establish a physics department in 1913, while Tsinghua was the latest, in 1926. On average, Peking produced nine BS graduates in physics per year; Tsinghua produced five, and Yenching two. ${ }^{130}$ In the early and middle 1930s, whereas the Department of Physics at Yenching at best had three senior faculty (one full and two associate professors), Peking and Tsinghua each had at least seven full professors teaching between 1931 and 1937 (see Table 7). Yet, it was Yenching that became the first to set up a master's program in physics in 1927, and nurtured the most MS in physics and physics researchers domestically before 1937-far more than the other two prestigious national universities combined.

Table 7: Physics faculty at Peking, Tsinghua, and Yenching Universities, 1931-1937

\begin{tabular}{|c|c|c|c|}
\hline University & Name of Senior Professors & Doctorate, awarding year \& university & In service \\
\hline \multirow{7}{*}{ Peking ${ }^{131}$} & Shou-Chin Wang 王守竞 & PhD, 1928, Columbia & $1931-1933$ \\
\hline & Yu-Tai Yao 饶毓泰 & PhD, 1922, Princeton & 1933-1937 \\
\hline & Wentworth Chu 朱物华 & PhD, 1926, Harvard & 1933-1937 \\
\hline & T. C. Chow 周同庆 & PhD, 1933, Princeton & $1933-1936$ \\
\hline & Tsung-Li Chang 张宗蟲 & PhD, 1933, Paris & 1933-1937 \\
\hline & Ta-You Wu 吴大猷 & PhD, 1934, Michigan & 1934-1937 \\
\hline & Hua-Chih Cheng 郑华炽 & PhD, 1934, TU Graz, Austria & 1936-1937 \\
\hline \multirow{7}{*}{ Tsinghua $^{132}$} & Chi-Sun Yeh 叶企孙 & PhD, 1923, Harvard & 1925-1937 \\
\hline & Yui-Hsun Woo 吴有训 & PhD, 1926, Chicago & 1928-1937 \\
\hline & Pen-tung Sa 萨本栋 & PhD, 1927, Worcester & 1928-1937 \\
\hline & Pei-Yuan Chou 周培源 & PhD, 1928, Caltech & 1929-1937 \\
\hline & Chung-Yao Chao 赵忠尧 & PhD, 1930, Caltech & 1932-1937 \\
\hline & Chih-kung Jen 任之恭 & PhD, 1931, Harvard & 1934-1937 \\
\hline & Ping-Chuan Ho 霍秉权 & 1931-1934, graduate study in Cambridge & 1935-1937 \\
\hline \multirow{3}{*}{ Yenching } & Yu-Ming Hsieh 谢玉铭 & PhD, 1926, Chicago & 1921-1937 \\
\hline & David King Yang 杨菍卿 & MS, 1927, Chicago & $1926-1934$ \\
\hline & William Band 班威廉 & MS, 1927, Liverpool & 1929-1937 \\
\hline
\end{tabular}

129 For the history of the departments at Peking and Tsinghua, see Shen and Zhao 2013, 17-32; $\mathrm{Hu}$ 1998, 60-78. For a discussion of the American refund of the Boxer Indemnity, see Hu 2016, 275-277.

130 Peking: 221/24; Tsinghua: 53/11; Yenching: 43/19.

131 Shen and Zhao 2013, 24; Hu 1998, 74-75. I thank Prof. Zhang Jian 张剑 for sharing with me his knowledge of Tsung-Li Chang; for the data concerning Chang's doctoral thesis, see Yuan 1964.

$132 \mathrm{Hu}$ 1998, 61-62. Ho does not seem to have received his $\mathrm{PhD}$ from the University of Cambridge, even though he studied three years and published a few papers there. 
The delay in establishing MS programs and paucity of MS graduates in the Peking and Tsinghua do not necessarily indicate the inferiority of their faculty or students, but rather demonstrate some unique features and certain advantages of Yenching as a mission college in China. First, Yenching did not fully rely on the recognition of the Chinese government for the granting of academic degrees as it was registered with the State of New York; 133 in contrast, Peking and Tsinghua were not allowed to grant any additional advanced degrees without the government's approval. In the case of master's degrees, since the Nanjing government did not promulgate relevant regulations until Spring 1935, Peking and Tsinghua were not able to confer any MS degrees before 1935. In fact, Peking did not even have a MS program in physics until 1935; Tsinghua started its MS program in 1929, but almost always had difficulty finding qualified applicants in the following eight years, except in 1933, when four men were admitted onto the program. This in turn reveals another factor that prevented the two national universities, especially Tsinghua, from developing their MS programs in physics: lack of enthusiasm or incentive to build up the research program domestically.

Peking launched its MS program too late to produce any graduates before it was forced to flee south in 1937 as a result of the Japanese invasion of Beijing. Tsinghua, on the other hand, began in 1911 as a preparatory school for students to be sent to study in America. It was not until 1925 that Tsinghua became a full college, producing its first four BS graduates in physics in 1929. None of these four graduates, however, continued their study in the newly established Tsinghua MS program in physics; instead, they either went to study overseas (two went abroad upon graduation and one left China one year later), or accepted teaching positions in China. Since two outside applicants also failed to pass the examination, nobody was admitted onto this Tsinghua MS program in 1929. ${ }^{134}$ Even those who were admitted did not seem to care much about completing their MS degree domestically if they had the opportunity to study abroad or acquire a teaching position. After failing to recruit any MS students in its first four years (1929-1933), the Tsinghua program welcomed four students in 1933: Jeoujang Jaw

133 Although Yenching University Regents had been granting degrees ever since its foundation in 1918, it was actually not until December 19, 1929 that the university was officially authorized to confer BA, BS, BD, MA, and MS degrees (Edwards 1959, 17-18).

134 The first Tsinghua College graduates in physics were Zhou Tongqing 周同庆, Shi Shiyuan 施士元, Wang Ganchang 王淦昌, and Zhong Jian 钟间. Whereas Zhou went to study with K. T. Compton in America and Shi sailed for France to study with Madam Curie, Wang was appointed as a teaching assistant at Tsinghua, where he served one year before going to study with Lisa Meitner in Berlin. At the current time, no information is available about what Zhong did immediately after his graduation from Tsinghua (The Research Department for the History of Tsinghua 1991, 561, 785; China Association for Science and Technology 1996, 411-412, 453, 460). 
赵九章, Cheng-Yi Fu 傅承义, Chien-Shan $\mathrm{Hu}$ 胡乾善, and Jwu-Shi Wang 王竹溪.135 Zhao stayed in the program for just one year before winning a scholarship, leaving to study in Germany in 1935. Fu also withdrew from the MS program in 1934 when he was appointed as an Assistant Professor at Tsinghua. Hu suspended his graduate study due to sickness soon after he started; but after he recovered, he acquired a government scholarship and left Tsinghua for study in Britain. It is said that among the four, only Wang completed his graduate study and received MS degree in 1935, probably just before his departure for the University of Cambridge, becoming the second and the last MS at Tsinghua before 1937.136 Apparently, almost all Tsinghua students preferred pursuing advanced training overseas instead of domestically, which was clearly encouraged by the university and its faculty then.

It should be added that Yenching produced at least ten additional MS graduates before it was shut down by the Japanese at the end of 1941;137 Tsinghua eventually awarded another seven MS degrees during 1937-1949, including the one earned by Shou-lien Chang 张守廉 (Hu 1998, 63); and Peking gave out only one, to Kun Huang, 黄 昆 (Shen and Zhao 2013, 45; “Huang Kun nianbiao” 黄昆年表 [A chronicle of Huang Kun] in Huang 2004, 627). It is worth pointing out that both Chang and Huang studied first at Yenching. Chang transferred to the National Southwest Associate University (NSAU) - a wartime refugee institution formed by the students and professors of Peking, Tsinghua, and Nankai Universities-in Kunming in 1940 before graduating from Yenching, while Huang joined Chang at the NSAU after earning his BS at Yenching in summer 1941 (Zhu 2002, 13-16). In fact, there were also Tsinghua graduates who chose to study in Yenching's MS program. For instance, Ping-Chuan Feng 冯秉铨 (Class 1930) and Ting-Sui Ke 葛庭燧 (Class 1937) from the Tsinghua Department of Physics earned their MS degree at Yenching in 1934 and 1940 respectively. ${ }^{138}$ This kind of frequent exchanges of students between Yenching and its Chinese counterparts benefited both sides, and helped advance physics education across China.

Despite its smaller number of faculty, the Department of Physics at Yenching University successfully built up the first, coeducational, and probably most prolific MS program in

135 The Research Department for the History of Tsinghua 1991, 638-640. Lu Xueshan, who apparently began his study in Tsinghua's MS program in physics in 1930, did not appear in the list of 1930 new graduate students, probably because Lu was already an Assistant Professor in the university when he enrolled in the program. Lu graduated in 1933, but likely did not receive his MS degree until after 1935, when relevant regulations concerning academic degrees had come into effect.

136 Jaw: Chao 1992, 275. Fu: Wang 1992, 290. Hu: Yang 1993, 104-112. Wang: Wang 1996, 1, 501, 512.

137 Based on my examination of the Yenching students' theses deposited in the Yenching University Archives at Peking University in Beijing.

138 On Feng's student years at Tsinghua and Yenching, see Yao 1987, 26-45. On Ke's time at Tsinghua and Yenching, see Liu 2011, 25-32, 383. 
China, training young men and women to become original researchers. Many of graduates from this program went on to earn their $\mathrm{PhD}$ degree overseas, and eventually became prominent physicists or scientific leaders in other professional fields, as shown in Table 8. It was indeed a significant and fertile cradle of Chinese physics researchers. Studying thoroughly the history of this remarkable institution should be enlightening for people endeavoring today to create world-class innovative private universities in China.

Table 8: Distinguished Yenching alumni in physics ${ }^{139}$

\begin{tabular}{|c|c|c|c|}
\hline Name & Degree/Class & Doctorate & Prominent accomplishments \\
\hline Chao-ying Meng 孟昭英 & $\begin{array}{l}\text { BS, 1928; } \\
\text { MS, } 1931\end{array}$ & $\begin{array}{c}\text { Caltech, } \\
1936\end{array}$ & $\begin{array}{l}\text { CAS Academician; chair, Physics Dept., Tsinghua Univ., } \\
\text { 1946-1952; chair, Radio Engineering Dept., 1952-1982; }\end{array}$ \\
\hline Wen-yu Chang 张文裕 & $\begin{array}{l}\text { BS, 1931; } \\
\text { MS, } 1932\end{array}$ & $\begin{array}{l}\text { Cambridge, } \\
1937\end{array}$ & $\begin{array}{c}\text { CAS Academician; known for his outstanding } \\
\text { achievements in the experimental research of nuclear } \\
\text { physics and cosmic ray physics; founder of the Institute of } \\
\text { High Energy Physics, CAS }\end{array}$ \\
\hline Ming-chen Wang 王明贞 & $\begin{array}{l}\text { BS, 1930; } \\
\text { MS, } 1932\end{array}$ & $\begin{array}{l}\text { Michigan, } \\
1942\end{array}$ & $\begin{array}{l}\text { Physics professor, Tsinghua U., 1955-1976; known for her } \\
\text { contributions to the theory of Brownian motion }\end{array}$ \\
\hline Sheng-lin Chu 褚圣麟 & MS, 1931 & $\begin{array}{l}\text { Chicago, } \\
1935\end{array}$ & $\begin{array}{c}\text { Chair, Physics Dept., Yenching Univ., 1945-1952 \& Physics } \\
\text { Dept., Peking U. 1952-1982; }\end{array}$ \\
\hline Te-hsien Pi 毕德显 & $\begin{array}{l}\text { BS, } 1932 ; \\
\text { MS, } 1934\end{array}$ & $\begin{array}{l}\text { Caltech, } \\
1944\end{array}$ & $\begin{array}{l}\text { CAS Academician; founder of radar engineering and } \\
\text { military communication engineering in China }\end{array}$ \\
\hline Chia-liu Yuan 袁家骝 & $\begin{array}{l}\text { BS, 1932; } \\
\text { MS, } 1934\end{array}$ & $\begin{array}{c}\text { Caltech, } \\
1940\end{array}$ & Senior physicist at Brookhaven National Laboratory \\
\hline Ping-chuan Feng 冯秉铨 & MS, 1934 & $\begin{array}{l}\text { Harvard, } \\
1943\end{array}$ & $\begin{array}{l}\text { Physics dept. chair, dean of sch. of science, Provost, } \\
\text { Lingnan U.; Vice-President of South China U. of Tech. }\end{array}$ \\
\hline Hsien-yu Hsu 徐献瑜 & MS, 1934 & $\begin{array}{l}\text { Washington, } \\
1938\end{array}$ & $\begin{array}{c}\text { Math. Dept. chair, Yenching U., founder of Chinese } \\
\text { computational mathematics }\end{array}$ \\
\hline Cheng-shu Wang 王承书 & $\begin{array}{l}\text { BS, 1934; } \\
\text { MS, } 1936\end{array}$ & $\begin{array}{l}\text { Michigan, } \\
1944\end{array}$ & $\begin{array}{l}\text { CAS Academician; first in China to carry out studies in } \\
\text { controlled thermonuclear fusion and plasma physics; } \\
\text { established and guided uranium isotope separation studies } \\
\text { in China with significant theoretical and practical } \\
\text { accomplishments }\end{array}$ \\
\hline Ho-fu Lu 卢鹤绂 & BS, 1936 & $\begin{array}{l}\text { Minnesota, } \\
1941\end{array}$ & $\begin{array}{l}\text { CAS Academician; professor, Fudan U.; discoverer of the } \\
\text { isotope effect of thermion emission }\end{array}$ \\
\hline Ting-sui Ke 葛庭燧 & MS, 1940 & $\begin{array}{l}\text { UC-Berkeley, } \\
1943\end{array}$ & $\begin{array}{l}\text { CAS Academician; known for the Ke-type pendulum and } \\
\text { Ke grain-boundary internal friction peak named after him; } \\
\text { recipient of the Zener Prize (1989) and Robert Franklin } \\
\text { Mehl Award (1999) }\end{array}$ \\
\hline Kun Huang 黄昆 & BS, 1941 & $\begin{array}{l}\text { Bristol U., } \\
1948\end{array}$ & $\begin{array}{l}\text { CAS Academician; a pioneer of semiconductor physics } \\
\text { research in China; known for his significant achievements, } \\
\text { such as Huang-Pekar's theory, Huang's Equation, and } \\
\text { Huang's Scattering; China's State Preeminent Science and } \\
\text { Technology Award (2001) }\end{array}$ \\
\hline Chia-lin Hsieh 谢家麟 & BS, 1943 & $\begin{array}{l}\text { Stanford U., } \\
1951\end{array}$ & $\begin{array}{l}\text { CAS Academician; guided the design, prefabrication } \\
\text { research, and construction of the Beijing Electron Positron } \\
\text { Collider as Project Director; China's State Preeminent } \\
\text { Science and Technology Award (2011) }\end{array}$ \\
\hline
\end{tabular}

139 The data in this table are synthesized from my study of Yenching student theses deposited in Peking University Library and of relevant biographies in Short biographies of Chinese specialists in science and technology 中国科学技术专家传略 [Zhongguo kexue jishu zhuanjia zhuanlüe], edited by China Association for Science and Technology. 


\section{Acknowledgments}

I thank Prof. Zhang Baichun 张柏春 for inviting me to contribute to this special issue of Chinese Annals of History of Science and Technology (CAHST), and I am indebted to the Institute for the History of Natural Sciences, Chinese Academy of Sciences for all the support and assistance I received to attend the CAHST workshop in Beijing. I also thank all the workshop participants and two anonymous referees for their inspiring comments and helpful suggestions, which have greatly improved this paper. I gratefully acknowledge the help of many friends and colleagues, especially Liu Xiwen 刘细文, William J. Haas, Zhang Jiuchen 张九辰, Yin Xiaodong 尹晓冬, Liu Jinyan 刘金 岩, Sun Lie 孙烈, Zhang Daqing 张大庆, Wang Yong 王勇, and Li Naishi 李乃适. I am deeply obliged to the following institutions for granting me access to their archival records: Manuscripts, Archives \& Special Collections of Washington State University (WSU) in Pullman, WA; Yale Divinity School Library (special collections); The United Board for Christian Higher Education in Asia; Rockefeller Archive Center; The London Missionary Society Archives at the School of Oriental and African Studies Library, University of London, UK; and Peking University Archives. This research project has been supported in part by PSC-CUNY Research Awards and by the Partner Group of Max Planck Institute for the History of Science at Capital Normal University. Last but not least, I wish to express my deep gratitude to the editors of the CAHST, especially Yu Yueyuan 俞月圆, John Moffett, and Lü Xin 吕昕, for their careful editorial work and great support.

\section{References}

\section{Archival sources}

London Missionary Society Archives at School of Oriental and African Studies Library, University of London in London, UK.

Rockefeller Foundation records in Rockefeller Archive Center, Sleepy Hollow, New York, US.

The United Board for Christian Higher Education in Asia Records deposited in the Special Collections of Yale Divinity School Library, New Haven, CT, US.

William Band Papers in Manuscripts, Archives, and Special Collections at Washington State University, Pullman, WA, US.

Yenching University Archives deposited in Peking University Archives, Beijing, China.

\section{Other references}

“Alumni Address." 1940. Wuli xuexun 物理學訊 [Yenching Physics News] (8): 22-24.

Anderson, Paul A. 1928. "The Electromotive Behaviour of Single Metal Crystals." Nature 123 (3089): 49. 
"A Story of Two Washingtons: The Earliest Electron Microscopes in America." 2003. Accessed August 4, 2016. https://www.microscopy.org/images/posters/washington.pdf.

Band, William. 1933. "Modern Theoretical Physics in China." Lingnan Science Journal 12 (May): 105-110.

Band, William. 1955. An Introduction to Quantum Statistics. Princeton, NJ: Van Nostrand.

Chandler, James G., and Stephen E. Novak. 2010. “Peking Union Medical College.” John Jones Surgical Society Newsletter 13 (2): 9-14.

Chang, C. S. Wang, and G. E. Uhlenbeck. 1951. Transport Phenomena in Polyatomic Molecules. Ann Arbor, MI: University of Michigan Publication.

Chang, C. S. Wang, and G. E. Uhlenbeck. 1970. "On the Propagation of Sound in Monatomic Gases." In Studies in Statistical Mechanics chap. iv: 43-75. Amsterdam: North-Holland Publishing Company.

Chao, Jiping 巢纪平. 1992. “Zhao Jiuzhang”赵九章 [Jeoujang Jaw]. In Zhongguo xiandai kexuejia zhuanji 中国现代科学家传记 [Biographies of modern Chinese scientists], edited by the editorial group of Grand dictionary of scientific biographies 《科学家传记大辞典》编辑组, vol. 3, 275-288. Beijing: Science Press.

Chu, Shenglin 褚圣麟, and Wu Ziqin 吴自勤. 1987. “Xie Yuming jiaoshou shilüe” 谢玉铭教授事 略 [A short biography of Yu-ming Hsieh]. Wuli 物理 (Physics) 16 (3): 185-186.

Crease, Robert P., and Charles C. Mann. 1986. The Second Creation: Makers of the Revolution in Twentieth-Century Physics. New York: MacMillan.

Del Regato, Juan A. 1978. “William Duane." International Journal of Radiation Oncology Biology Physics 4 (7-8): 717-729.

Donaldson, Edward E., and J. Thomas Dickinson. 1998. "Pioneering Research on Work Functions in Ultra-High-Vacuum at W.S.U. (unpublished)." Department of Physics and Astronomy, Washington State University.

Dong, Guangbi 董光璧. 2009. Zhongguo xiandai wulixue shi 中国现代物理学史 [A history of physics in modern China]. Jinan: Shandong Education Press.

Edwards, Dwight W. 1959. Yenching University. New York: United Board for Christian Higher Education in Asia.

“The Eighth Annual Meeting of the Chinese Physical Society." 1940. Wuli xuexun (8): 21.

Ferguson, Mary E. 1970. China Medical Board and Peking Union Medical College: A Chronicle of Fruitful Collaboration, 1914-1951. New York: China Medical Board of New York.

Foreign Missions Conference of North America, and Charles I. Boynton. 1927. The Missions Code, Comp. and Pub. by Authority of the Foreign Missions Conference of North America. Fourth edition. New York: Foreign Missions Conference of North America.

Haas, William J. 1996. China Voyager: Gist Gee's Life in Science. Armonk, NY: M. E. Sharpe.

Heilbron, J. L., and Robert W. Seidel. 1989. Lawrence and His Laboratory: A History of the Lawrence Berkeley Laboratory, California Studies in the History of Science. Berkeley: University of California Press.

Hu, Danian 胡大年. 2016. “American Influence on Chinese Physics Study in the Early Twentieth Century." Physics in Perspective 17 (4): 268-297.

$\mathrm{Hu}$, Shenghua 胡升华. 1998. “20 shiji shangbanye Zhongguo wulixue shi” 20 世纪上半叶中国物 理学史 [Chinese physics development during the first half of the 20th century]." PhD diss., 
University of Science and Technology of China.

Huang, Kun 黄昆. 2004. “Huang Kun nianbiao” 黄昆年表 [A chronicle of Huang Kun]. In Huang Kun wenji 黄昆文集 [Collected papers of Huang Kun]. Beijing: Peking University Press. Hwang, Lechung Tsetung 黄子通. 1935. “Huaidehai de shikongguan”懷德海的時空觀 [Whitehead's view of space-time]. Zhexue pinglun 哲學評論 [The Philosophical Review] 6 (1).

“J. B. Tayler to W. Band, Peking, March 14, 1929." 1929. Records of the Council for World Mission, Box 27, Folder 2073, London Missionary Society Archives at the School of Oriental and African Studies Library, University of London.

Kuno, Yoshi S. 1928. Educational Institutions in the Orient, with Special Reference to Colleges and Universities in the United States. Berkeley, Calif.: University of California.

Liu, Shen 刘深. 2011. Ge yu he: Ge Tingsui He Yizhen zhuan 戈与荷一一葛庭燧、何怡贞传 [A biography of Ting-Sui Ke and I-Chen Ho]. Beijing: Tsinghua University Press.

Luo, Bingxian 骆丙贤, ed. 2001. Wuli jiaoyushi 物理教育史 [A history of physics education]. Changsha: Hunan Education Press.

Lutz, Jessie Gregory. 1971. China and the Christian Colleges, 1850-1950. Ithaca: Cornell University Press.

Ma, Qiusha. 2002. “The Peking Union Medical College and the Rockefeller Foundation's Medical Programs in China." In Rockefeller Philanthropy and Modern Biomedicine: International Initiatives from World War I to the Cold War, edited by William H. Schneider. Bloomington: Indiana University Press.

Meng, Chao-Ying 孟昭英. 1982. “Yanjing Daxue Wulixi de bianqian” 燕京大学物理系的变迁 [The evolution of the Department of Physics at Yenching University]. Wuli 11 (11): 653-654.

NAS Archives. "NRC Rockefeller Fellowships, Fellowship Applications, Paul Alexander Anderson." 1929-1931. Deposited at the National Academy of Sciences, Washington, DC.

National Research Council (US). 1944. National Research Fellowships, 1919-1944: Physical Sciences, Geology and Geography, Medical Sciences, Biological Sciences. Washington, DC.

Nobelprize.org. n.d. “Willis E. Lamb: Facts." www.nobelprize.org/nobel_prizes/physics/ laureates/1955/lamb-facts.html.

Pan, Yongxiang 潘永祥, Wu Ziqin, and Fan Shulan 范淑兰. 1993. “Yanjing Daxue wulixuexi shigao" 燕京大学物理学系史稿 [Draft history of the Department of Physics at Yenching University]. Wuli 22 (8): 493-500.

"Physicist Is Killed By Shock." 1937. Columbia Daily Spectator, March 22, 1937.

Qian, Weichang 钱伟长, and Chen Jia'er 陈佳洱. 2014. 20 shiji Zhongguo zhiming kexuejia xueshu chengjiu gailan: Wulixue juan 20 世纪中国知名科学家学术成就概览 - 物理学卷 [An overview of eminent Chinese scientists' achievements in the 20th century: Physics] vol. 1. Beijing: Science Press.

The Research Department for the History of Tsinghua 清华大学校史研究室. 1991. Qinghua Daxue shiliao xuanbian 清华大学史料选编 [Selected historical documents on Tsinghua University] vol. 2 (part II). Beijing: Tsinghua University Press.

The Rockefeller Foundation. n.d. "Selskar M. Gunn." Accessed October 3, 2019. https:// rockfound.rockarch.org/biographical/-/asset_publisher/6ygcKECNI1nb/content/selskar-mgunn.

The Rockefeller Foundation, ed. 1919. The Rockefeller Foundation Annual Report for 1919. New York: 
The Rockefeller Foundation.

The Rockefeller Foundation China Medical Board. 1918. "Third Annual Report, January 1, 1917-December 31, 1917." New York, NY. https://books.google.com/books?id=mCGgAAA AMAAJ\&printsec $=$ frontcover\&source $=$ gbs_ge_summary_r\&cad $=0 \# \mathrm{v}=$ onepage\& $\mathrm{q} \& \mathrm{f}=$ false .

Texas Archival Resources Online. n.d. "Guide to the William V. Houston personal papers, 1925-1968, bulk 1941-1968 MS 426." http://www.lib.utexas.edu/taro/ricewrc/00056/ rice-00056.html.

Shen, Keqi 沈克琦, and Zhao Kaihua 赵凯华, eds. 2013. Beida wuli bainian 北大物理百年 [Centenary of physics at PKU]. Unofficial publication. Beijing: Peking University.

Smith, Harold Frederick, and Charles Hodge Corbett. 1965. Hunter Corbett and His Family. Claremont, Calif.: College Press.

Stifler, William Warren. 1908. "Change of electrical resistance in a magnetic field: with experiments on the change of resistance of electrolytes." AM thesis, UIUC.

Stifler, William Warren. 1911. "The magnetization of cobalt as a function of the temperature and the determination of its intrinsic magnetic field." PhD diss., UIUC.

Stifler, William Warren. 1923. Exercises in Elementary Physics, 1st ed. Shanghai: The Commercial Press.

Stuart, John Leighton. 1954. Fifty Years in China: The Memoirs of John Leighton Stuart, Missionary and Ambassador. New York: Random House.

Sun, Hong'an 孙宏安. 2006. Zhongguo jinxiandai kexue jiaoyu shi 中国近现代科学教育史 [A history of modern science education in China]. Shenyang: Liaoning Education Press.

University of Chicago. 1922. Annual Register, 1922-1923. Chicago: University of Chicago Press.

van der Wall, Ernestine. 2007. The Enemy within: Religion, Science, and Modernism. Uhlenbeck Lecture. Vol. 25, Wassenaar, the Netherlands: Netherlands Institute for Advanced Study.

Wang, Guangfu 王广福. 1992. “Fu Chengyi” 傅承义 [Cheng-Yi Fu]. In Zhongguo xiandai kexuejia zhuanji, edited by the editorial group of Grand dictionary of scientific biographies, vol. 3, 289-301. Beijing: Science Press.

Wang, M. C., and G. E. Uhlenbeck. 1945. "On the Theory of the Brownian Motion-II." Reviews of Modern Physics 17 (2-3): 323-342.

Wang, Zhengxing 王正行. 1996. “Wang Zhuxi” 王竹溪 [Jwu-Shi Wang]. In Wulixue juan 物理学 卷 [Physics] vol. 1: 500-515. In Lixue bian 理学编 [Natural sciences \& mathematics section] of Zhongguo kexue jishu zhuanjia zhuanlüe 中国科学技术专家传略 [Short biographies of Chinese specialists in science and technology], edited by China Association for Science and Technology. Shijiazhuang: Hebei Education Press.

Wei, Pei Hsiu 魏培修. 1929. “Chemical Decomposition by Slow Electrons.” MS thesis, Yenching University.

Wellesley College, ed. 1922. Wellesley College Bulletin: Calendar 1922-1923 vol. 11, no. 7. Boston, Mass.: Insurance Press, Inc.

West, Philip. 1976. Yenching University and Sino-Western Relations, 1916-1952. Harvard East Asian series. Cambridge, Mass.: Harvard University Press.

Wu, Ching-huan 吴敬寰. 1929. “The Rectification of Alternating Current by Crystals with Metallic Contact." MS thesis, Yenching University.

Yale University President's Office. 1922. Reports Made to the President of Yale University. Tuttle, 
Morehouse \& Taylor Company.

Yang, Hanguo 杨汉国. 1993. “Hu Qianshan” 胡乾善 [Chien-Shan Hu]. In Lixue juan 力学卷 [Mechanics] vol. 1: 104-112. In Gongcheng jishu bian 工程技术编 [Engineering \& technology section] of Zhongguo kexue jishu zhuanjia zhuanlüe, edited by China Association for Science and Technology. Shijiazhuang: Hebei Education Press.

Yanjing Academic Research Institute 燕京研究院, ed. 2001. Yanjing Daxue renwuzhi 燕京大学人物 志 [Who's who in Yenching University] vol. 1. Beijing: Peking University Press.

Yao, Shuhua 姚树华. 1987. Feng Bingquan jiaoshou de daolu 冯秉铨教授的道路 [The path of Professor Ping-Chuan Feng]. Guangzhou: South China Institute of Technology Press.

Yuan, Tung-li 袁同礼. 1964. A Guide to Doctoral Dissertations by Chinese Students in Continental Europe, 1907-1962 (I). Chinese Culture: A Quarterly Review V (3): 92-156.

Zearott, Sabrina. 2013-2014. "95 Years of Physics: The Department, Its Leaders, and the Research that Helped Make It Great." Physics Matters 17: 22-27.

Zhang, Weiying 张玮瑛, Wang Baiqiang 王百强, and Qian Xinbo 钱辛波, eds. 2000. Yanjing Daxue shigao, 1919-1952 燕京大学史稿: 1919-1952 [A draft history of Yenching University: 1919-1952]. Beijing: The Publishing House of People's China.

Zhongguo Wuli Xuehui liushi nian 中国物理学会六十年 [The sixty years of the Chinese Physical Society]. 1992. Changsha: Hunan Education Press.

Zhu, Bangfen 朱邦芬. 2002. Huang Kun: Shengzi wuli diyi ren 黄昆一一声子物理第一人 [Huang Kun: The first man in phonon physics]. Shanghai: Shanghai Scientific and Technical Publishers. 